\title{
Socio-demographic backwardness in cyclone prone coastal villages: An Insight from Indian Sundarban
}

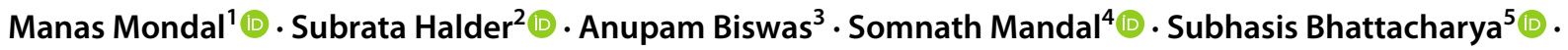 \\ Suman Paul ${ }^{6}$ (1)
}

Received: 29 October 2021 / Revised: 19 November 2021 / Accepted: 19 November 2021 / Published online: 13 January 2022

(c) The Author(s), under exclusive licence to Springer Nature Switzerland AG 2021

\begin{abstract}
The capability to design for, respond to, and recover from natural hazards is much influenced by demographic and socioeconomic vulnerability of the region. Triggering effect of cyclone induced multi-hazards in the coastal areas of West Bengal, India makes the life and livelihood of people miserable. Very recent cyclones, like, Fani, Bulbul, Amphan and Yaas make people much more susceptible to hazard with the evil impact of on-going pandemic. According to IPCC, sensitivity and adaptive capacity analysis at micro level is taking much importance to address the readiness situation of the region. In this backdrop, the study aims to assess and map the level of demographic and socio-economic backwardness at village level for Kakdwip coastal area under coastal West Bengal, India. Applying principal component analysis we have tried to find out the level of demographic and socio-economic backwardness at different geographical locations (categorise as inland, riverine/ estuarine, coastal and island). The final findings suggest that backwardness is more prevalent in the southern part of the research region, with island and riverine/ estuary villages being particularly vulnerable. When the results have tries to find out the triggering factors at different geographical locations, female and child population, land holdings and earning of household came as the dominant factors for such higher degree of backwardness. These findings, when combined with micro level assessments, could help village administrators, planners and policymakers, and emergency managers design more effective and spatially tailored backwardness management plans.
\end{abstract}

Key Words Demographic structure $\cdot$ Socio-economic $\cdot$ Cyclones $\cdot$ Coastal area $\cdot$ Backwardness

\section{Introduction}

Backwardness is a shortfall of progress by an individual or get-together to some evident financial norm of progress. It is ordinary social wonder which subverts both life and property around there (Cutter et al. 2003; Cutter and Morath 2014;

Suman Paul

suman.krish.2007@gmail.com

Manas Mondal

manasaparna@gmail.com

Subrata Halder

s.haldar90@gmail.com

Anupam Biswas

anupambiswas1991@gmail.com

Somnath Mandal

mandal.somu1@gmail.com

Subhasis Bhattacharya

suva69eco@gmail.com
Aksha et al. 2018). Monetary condition is a huge marker to grasp the level of backwardness of any district. In India, there exist many dimensions of social and monetary perplexity because the concept of backwardness was contradictory with the country's worldview (Desai 1984). More than $50 \%$ of the general population really can't fulfil their

1 Department of Geography, Sidho Kanho Birsha University, W.B, Purulia 91-8777845227, India

2 Department of Geography, Sidho Kanho Birsha University, W.B, Purulia 91- 824014721, India

3 Department of Geography, Sidho Kanho Birsha University, Purulia, W.B 91- 9547820217, India

4 Department of Geography, Sidho Kanho Birsha University, W.B, Purulia 91- 9903000522, India

5 Sidho Kanho Birsha University, W.B, Purulia 91- 8617730258, India

6 Sidho Kanho Birsha University, W.B, Purulia 91- 9433135171, India 
fundamental prerequisites in this country. The McKinsey Worldwide Foundation Report (2015), charged by the Indian government, found that $56 \%$ of the general population or 680 million people, really don't have the best approach to address basic issues, for instance, food, energy, dwelling, drinking water, sanitization, clinical consideration, guidance and federal retirement aide (Ghosh et al. 2007). The survey also detects large geographic inconsistencies in the openness of social establishment, which are notably noticeable in the field of basic simple advice and, in particular, in learning outcomes (Sekhar et al. 1991; Majumder 2005; Das and Misri 2013). The variations in fundamental preparing in the country are generally thought to be caused by monetary situations (Szabo et al. 2016; Das et al. 2020). Social imbalances of sex, rank, class and religion have been distinguished as significant reasons for instructive backwardness in India (Singh 2006; Nayak and Narayankar 2009; Saboor et al. 2015).

A few observational examinations have been exhibited that group environment is incredibly huge in the field of simple tutoring in India (Govinda and Varghese 1993). Informative contrasts, which contribute a notable game plan to the assurance of monstrous variations in Indian culture, in like manner for the most part, get from more essential uneven characters, for instance, those of class rank and sexual direction". The social backwardness reliably suffers with money related backwardness and conflicting social and monetary establishment significantly impacts children's permission to guidance and their interest in the learning cycle (Angadi 2012; Saboor et al. 2015). In future low tutoring level basically sway low compensation level of an individual or social affair and they didn't get adequate degree to get to ideal monetary offices (Dholakia 2003; GoI 2013). As a result backwardness is ordinary part in their regular daily existence. They are changed in this structure. India is a rural country and in present perspective various zones are running in monetary backwardness condition. As prescribed by Liu and $\mathrm{Li}$ (2016), the speculation of spatial division and the possibility of 'advancement shafts' suggest that the free working of market measures in business person social orders accentuates nearby lopsided characters, with the ultimate objective that rich territories become more extreme and less lucky. Thus, spatial improvement polarization causes monetary abnormalities that are followed by friendly differences. In the face of prevailing issues, debates, and political strife in India, the theory of spatial polarisation appears to have been a necessary work. It is noteworthy that India has transformed itself from a farming country with low pay rates to a nonmodern country with a focus profit, despite the fact that it has consistently stayed out of the path of its monetary turn of events (Dholakia 2003; GoI 2013). The little level affirmation of regional lopsided characteristics and the evaluation of nearby improvement designs are critical components that sway procedure plan (Rufat et al. 2015; Dintwa et al. 2019). In the system paper for India's twelfth Five-Year Plan (20122017), the Planning Commission (2011) underlined with a fitting title: "Quicker, Reasonable and More Comprehensive Development" to connect commonplace portion and monetary differences.

Anyway association with hazards whether it is ordinary or manufactured is a normal issue. Hazard is along these lines seen as the fiasco situation, wherein some threat of disaster exists considering the way that the human people has set itself in condition of shortcoming (Hahn et al. 2009 ; Basu and Das 2020). Is it simply the natural perils winning there, or the impacts of ordinary dangers on the people which is disclosing the overall helplessness? This presents two thoughts, for instance 'environmental shortcoming's and 'social weakness'. Ecological shortcoming infers, how much the territory is lost its normal condition normally, for instance the influence and repeat of the environmental perils looked by the space and social shortcoming suggests weakness of the overall population to incidents coming about on account of ordinary danger occasions (Sen 1993; Bakshi et al. 2015). Sen (1999) took apart vulnerability as a limit with respect to mishap got from the exchange of society with bio-significant conditions which in flip influence the flexibility of the ecological components to reply to the risk or calamity in development to influence the assortment of society to such changing over circumstances (Chen et al. 2013; Alam 2017). This indicates the association between normal shortcoming and social shortcoming of any area. In this manner it will in general be all around perceived that if an area is normally unprotected, it is socially feeble as well.

Backwardness of any site depends on its space and genuine ascribes (environmental shortcoming) and the level of monetary new development (social new development) of the same (Dube and Sekhwela 2008; Motsholapheko et al. 2011). So it will in general be said that a retrogressive spot with least made system and basic dependence on normal resources is likewise more vulnerable. In India there are various sea shore front where structure is least developed and thus monetary progression is low and people live in with incapable regular condition (Dwarakish et al. 2009; Mahendra et al. 2010). A sudden unnatural condition in trademark wonder makes debacle in such areas which makes it a feeble in section and monetary condition. Finally these powerless conditions changes into backwardness (Hossain 1993; Eriksen and Kelly 2007).

Vulnerability of any area depends on its space and genuine ascribes (environmental shortcoming) and the level of monetary new development (social new development) of the same (Bjarnadottir et al., 2011; IPCC 2014). So it will in general be said that a retrogressive spot with least made system and basic dependence on normal resources is likewise more vulnerable (Hegde and Reju 2007; Vvas 
and Kumaranayake 2010; TERI 2014). In India there are various sea shore front where structure is least developed and thus monetary progression is low and people live in with feeble regular condition. A sudden unnatural condition in trademark wonder makes debacle in such areas which makes it a feeble in section and monetary condition. Finally these incapable conditions changes into backwardness (Vincent and Cull 2010).

In the low lying shoreline dynamic deltaic regions of West Bengal, people are routinely looked by strong and disastrous event of cyclone, floods and related cyclonic flood, river flood, salinization, embankment breaching and loss of biodiversity (Banerjee et al. 2012, Sahana et al., 2019). These ordinary threats make the people of such waterfront regions are biologically and socially more powerless. Organization weakness phenomenally the social weakness is the critical concern here (Sarker et al., 2003; Choudhury et al. 2005). Social weakness transmits from social segments of those spot people in significantly revealed zones, impact the affectability of people to uncover and affect their capacity to respond and change (Panthil et al. 2015). The state of consistent cognizance of the purposes behind hazard shortcomings, as well as the ideas put forth by investigators to mitigate these shortcomings, was examined in this assessment, which revealed critical inadequacies in the importance of existing intelligent investigation in providing appropriate and relevant information to methodology and practise (Manthalu et al. 2010; Ghosh et al. 2018). Openings exist, explicitly, in the usage of hypothetical theory in shortcoming examination, the improvement of operational methods critical for performers at the sub-public level, and the arrangement of strong proposition that address the primary secret explanations behind shortcoming (Mondal et al., 2020). Inside $100 \mathrm{~km}$ of waterfront regions, 23 per cent of all out people lives with different risks and such novel piece of earth's surface is the touchiest part as this region is living space of mangroves, wetlands, coral reefs (Alam et al. 2017; Sahana et al., 2019). These bits of landmass face a couple of kinds of risks, for instance, storm and sriver flood, sea level rising, coastal embankment breaching, salinization with complex power during a decade ago (Mondal et al., 2021).

The above-mentioned analyses are suitable to find out the actual situation of socio-demographic backwardness in cyclone prone coastal villages at Sundarban region of coastal West Bengal which is witnessed of rapid intensification of coastal hazards (like cyclones, embankment breaching, salinisation, bank erosion etc.) during last 10-15 years. The Specific objectives of the study are to -

- Evaluate the level of backwardness at coastal villages in respect of demographic and socio-economic attributes lies in the study area
- Categorize the nature of backwardness at coastal villages at a single frame and

- Determine the factors associated with backwardness at coastal villages.

\section{Geographical and administrative setting of the study area}

Sundarban is arranged in extreme southern section of coastal side West Bengal and connected in South and North 24 Parganas locale. One of the interesting ones is the Sundarban Biosphere Reserve (SBR) as World heritage regions with their incredible mangrove plants (Sahana et al. 2020). It stretches out across $21^{\circ} 30^{\prime}$ to $22^{\circ} 40^{\prime} \mathrm{N}$ latitudes and $88^{\circ} 05^{\prime}$ to $89^{\circ} 55^{\prime} \mathrm{E}$ longitudes. This SBR 19 squares of (administrative sub-divisions of the area). The mangrove forest has a zone of approximately 140,000 hectare with a gigantic area of territory features on the delta of the streams Ganga, Meghna and Brahmaputra, including streaming mudflats, exchanges, streams and islands (Gopal and Chauhan 2006). These streams pass on with them a ton of residue and get settled the delta. The discontinuous debacles in the Save are cyclones, flooding and cyclonic floods (Juran and Trivedi 2015; Sahana et al. 2021). Such catastrophes have made critical adversities establishment, land, creatures and homes. Diverse water borne sicknesses spreading as a result of water stagnation are moreover influencing the local networks. Mangroves and maritime organic frameworks are moreover influenced by rising sea temperatures (Fuchs et al. 2012; Hummell et al. 2016). On account of the rising sea level, the assessment locale has seen the submergence of a couple of islands. In like manner, the interference of pungency, neighborhood network dependence on forests and developments in cultivating designs are adjusting the SBR's natural status. The serious level of openness and weakness of this deltaic climate has given a hindrance to the network transformation. The assessment of multi-risk occasions and their impact on the financial circumstance is in this manner of essential worry for the security of the seaside network's inclinations (Papathoma-Kohle et al. 2011; Letsie and Grab 2015). The current investigation intends to dissect the segment and financial backwardness related with beach front multi-danger occasions in the towns under Kakdwip subdivision of South Parganas area in detail. This investigation is a lacking undertaking to use Multi-direct backslide model since of multi-peril events in the examination zone change backwardness in portion and socio-monetarily. The assessment region has been isolated into geomorphologically and administrative perspective further. Geomorphologically, towns under the assessment zone have been apportioned into waterfront, riverine and inland regions. Of course in administrative perspective; fragment and monetary backwardness 
evaluation has been done on Sagar, Namkhana, Pathar Pratima and Kakdwip blocks.

The Kakdwaip region contains 202 villages under four Community Development Blocks, in particular Kakdwip, Namkhana, Pathar Pratima and Sagar challenging multi-hazards constantly and its tendency and rate is expanding step by step. Loss of lives, steers and horticultural misfortune are the regular features of these Gram Panchayats. Perennial waterways, for example, Hugli, Gabtala, Muriganga, Saptamukhi, Kalindi, Bidyadhari, Raimangal and their distributaries go through Gangetic delta, making these towns more inclined to flooding (Gopal and Chauhan 2006). In general cyclonic tempests and stream immersion make the locale more defenceless. Specific, flare-up of floods has been accounted for twelve continuous years during 2001-2020. The intensity of these occasions was generally higher during the late $20^{\text {th }}$ century and the most recent decade, and caused remarkable death toll and property in the beach front squares of South 24 Parganas district (Fig. 1).

Data are the soul of the present associations, and the powerful and proficient administration of information is viewed as an essential piece of authoritative system. Effective associations should gather top notch information which will prompt high calibre of data. For a fruitful and powerful administrative dynamic, it is important to give precise, convenient and pertinent data to leaders. This demonstrating and finished up danger appraisal study helps the leaders in administrative knowledge with thinking about some genuine suppositions of weakness in the field of risk and openness, affectability and cultural adaptivity among the towns of the investigation squares of South 24 Parganas, West Bengal, India. Dataset has been taken up to July 2020 and inside these periods an enormous number of cyclones viz., Aila, Sidr, Vayu, Fani, Bulbul, Amphan and Yaas occurred in the seaside West Bengal and these are expressed in (Fig. 2).

\section{Materials and Methodology}

Choice and grouping for any exact exploration is a troublesome assignment as the idea of result tremendously relies upon this determination. Here we have developed an index and named as 'DSoB Index' (demographic and socio-economic backwardness index termed as $D S o B I$ ) to comprehend the drivers of backwardness at the village level in Kakdwip sub-division, West Bengal, India. Using the several research findings, we institute significant factors on demographic and socio-economic backwardness points of view.

\section{Selection of indicators and data source}

The social vulnerability index introduced by Cutter et al. (2003), which used more than 200 variables in the United
States to measure and evaluate social vulnerability, was modified and implemented in this research. Social vulnerability conceptualizations and the SoVI approach have been refined over time and applied in lots of ways (Boruff and Cutter 2007; Holand and Lujala 2013; Zhou et al. 2014; Hummell et al. 2016). Similarly, in order to build a modified DSoBI (demographic and socio-economic backwardness index) for Kakdwip, this study examined individual factors such as demography, education, education, ethnicity, and health, as well as community characteristics such as access to demographic and socio-economic backwardness attributes. As the original SoVI was adapted to the context of the United States, modifications were required to adapt the model to the separate demographic and socio-economic backwardness context of Kakdwip. We extracted data from the full dataset of the most recent 2011 Socio-economic Caste Census, provided by the Ministry of Rural Development (CBS), Government of India, to create the DSoB Index. Using two household level questionnaires, SECC conducted the census. The first questionnaire gathered basic demographic data, and the second questionnaire included more comprehensive questions on issues economic parameters. In this analysis, 25 precise and accessible variables were used, as most of the knowledge was not strictly linked to DSoBI (demographic and socio-economic backwardness index) to natural hazards which are under 5 components. Table 1 displays the definition and data source of indicators used in this analysis.

\section{Method}

To understand the socio-economic backwardness due to multi scale hazard of the said region in block wise two most important approaches have been taken a) normalization of variables using Simple Quotient Method after reliability analysis and b) apply PCA to determine the level of backwardness. After deriving the backwardness value at village level, multivariate-ordinal logistic regression has been employed to take proper steps by the governmental and nongovernmental organisation to combat with the regional multi-hazards issues. The methodology finally developed and describe in flow chart in Fig. 3.

\section{Preparation of dataset using reliability analysis}

Twenty five indicators have been taken into consideration to analyze the backwardness of the study villages which have categorized into five dimensions, i.e. demography, built environment, education, economy and asset. In application to demonstrate the inside unwavering quality of the model utilized, the authors have experienced Cronbach's Alpha analysis of dependability. Applying this test determines whether the things relating to each measurement are 


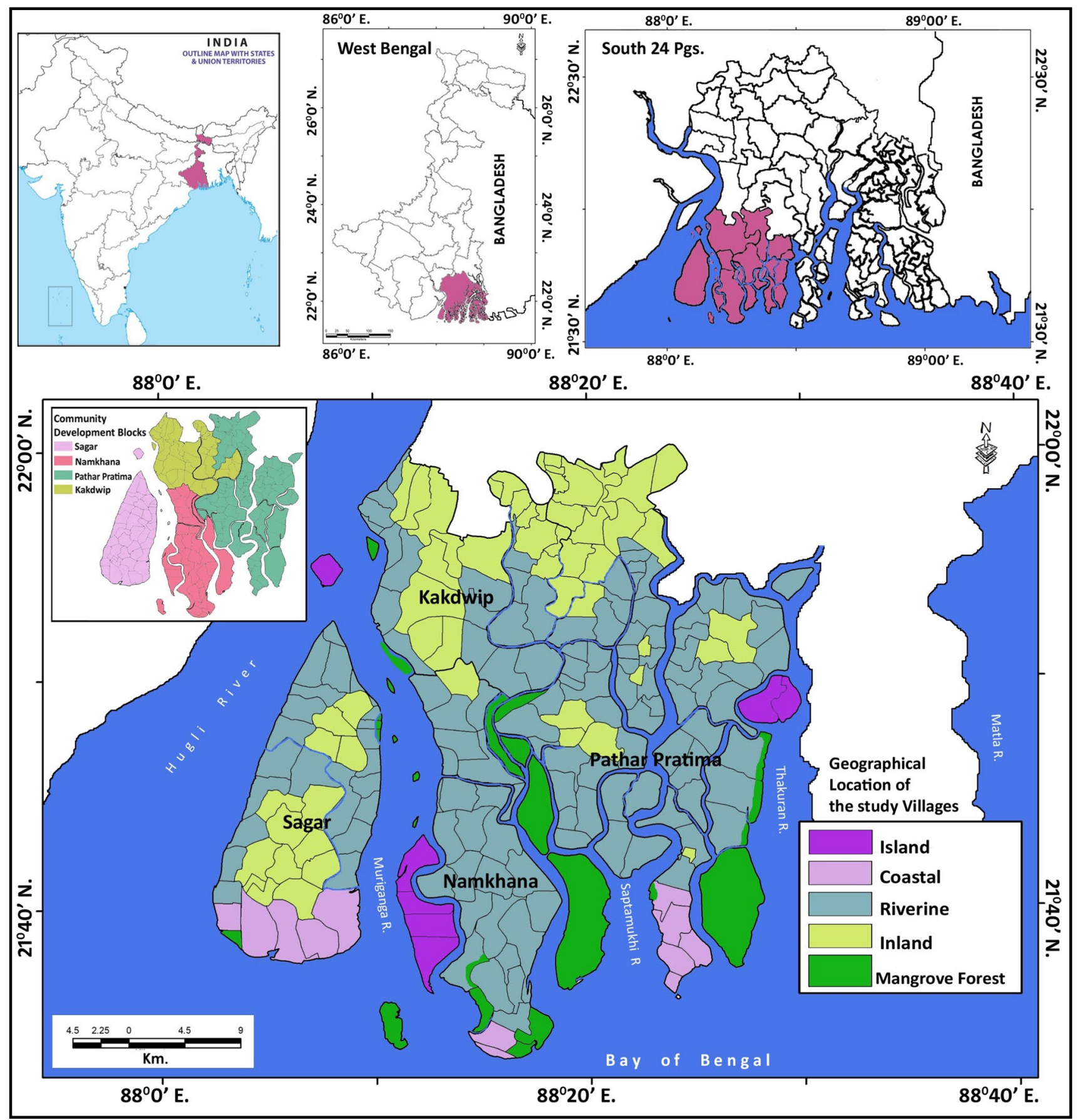

Fig. 1 Location of the study area and classification of study village on geographical characteristics for Kakdwip Subdivision, West Bengal, India

inside reliable and whether they can be utilized to gauge a similar develop or measurement of administration quality. As indicated by Nunnally (1978), Cronbach's Alpha ought to be 0.700 or above. Yet, in a portion of the investigations, 0.600 is additionally viewed as adequate (Helms et al. 2006; Kenova and Jonasson 2006). Table 2 show Cronbach's Alpha precision over 0.60 for 17 variables further. In this way, these things were dispensed with from the factor examination. In any case, if Cronbach's Alpha estimation of all things were satisfactory, it implies that the current information would be appropriate for factor analysis.

\section{Simple quotient ratio (SQR)}

In simple quotient method it is another simple but meaningful method of interval or ratio data transformation and 


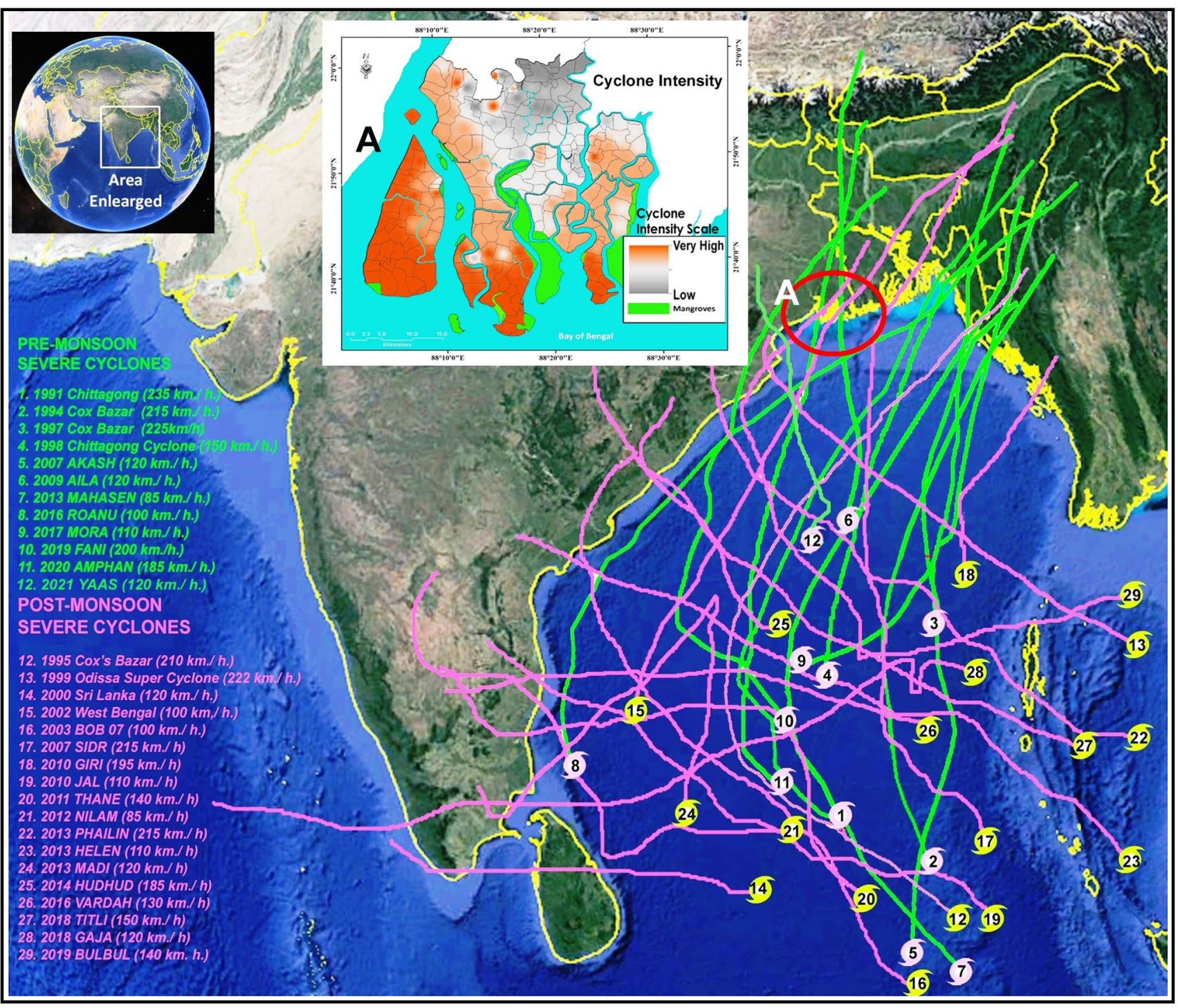

Fig. 2 Cyclonic tract in Bay of Bengal basin during last 30 years and cyclonic intensity in the study area (in Inset: A)

computation of scaled free composite score. In this method, individual values of various indicators with different units of measurement are converted into unit-less value by dividing an individual value of an indicator by the corresponding mean value of that indicator.

$\mathrm{Y}=\mathrm{Xi} / \mathrm{x}$

where ' $\mathrm{Y}$ ' is the normalised value of variables, ' $X i$ ' represents its value of variables and ' $x$ ' is mean of same variable. In this methodology at first we have taken 25 variables and simple quotient method has been applied for the normalization of these variables. Prior to aggregating all standardized indicating variables, a weight is assigned to each variable following either the equal-weighting system (where each variable is equally important, and equal weights are assigned to each) or unequal-weighting system (where each variable is disproportionately important, and unequal weights are assigned to each). Applying equal weight to all indicating variables is not justifiable because all variables are not equally important. Each indicating variable affects hazard related vulnerability differently. So, we have applied unequal weight to all variables and determine the weight for each indicating variables using the simple quotient method.

\section{Principal component analysis (PCA)}

Hotelling (1933) has licensed for the advanced of numerical establishment of Principal component analysis (PCA). To discover the degree of imbalance, PCA has been finished with 25 indicators for 202 villages situated in four C.D. Blocks under Kakdwip Region, West Bengal. The PCA is 
Table 1 Indicators listed before applying Cronbach's Alpha test of reliability

\begin{tabular}{|c|c|c|c|}
\hline Compo-nents & Indicators & $\begin{array}{l}\text { Studies related to backwardness } \\
\text { assessment previously }\end{array}$ & Data source \\
\hline \multirow[t]{6}{*}{ Demography } & Adult Dependency & Krishnan et al., 2018 & SECC, 2011 \\
\hline & Youth Dependency & Krishnan et al., 2018 & SECC, 2011 \\
\hline & Female Population & Juran and Trivedi, 2015 & PCA, 2011 \\
\hline & Sex Ratio & Islam and Hasan, 2015 & PCA, 2011 \\
\hline & SC and ST Population & Sahana et al., 2020 & PCA, 2011 \\
\hline & $\begin{array}{l}\text { Female headed households with no adult } \\
\text { male member between age } 16 \text { to } 59 \text { Yrs. }\end{array}$ & Juran and Trivedi, 2015 & SECC, 2011 \\
\hline \multirow[t]{6}{*}{ Built environment } & HHs without Electricity & Krishnan et al., 2018 & HLPCA, 2011 \\
\hline & HHs without Safe Drinking Water Facility & Krishnan et al., 2018 & HLPCA, 2011 \\
\hline & HHs without Sanitation & Nayak and Narayankar, 2009 & HLPCA, 2011 \\
\hline & HHs with Kutcha House & Basu and Das, 2020 & HLPCA, 2011 \\
\hline & HHs Roof without Non-Permanent Structures & Basu and Das, 2020 & HLPCA, 2011 \\
\hline & HHs Wall without Non-Permanent Structures & Basu and Das, 2020 & HLPCA, 2011 \\
\hline \multirow[t]{3}{*}{ literacy } & Illiterate & Liu and $\mathrm{Li}, 2016$ & PCA, 2011 \\
\hline & Population who have completed $10^{\text {th }}$ Standard & Liu and Li, 2016 & PCA, 2011 \\
\hline & No literate adult above 25 years & Mondal et al., 2020 & PCA, 2011 \\
\hline \multirow[t]{6}{*}{ Economy } & HHs Owing Land & Liu and $\mathrm{Li}, 2016$ & SECC, 2011 \\
\hline & Share of Population in Primary Activities & Islam and Hasan, 2015 & SECC, 2011 \\
\hline & Deprived HHs & Mondal et al., 2020 & SECC, 2011 \\
\hline & HHs having Kishan credit card & Mondal et al., 2020 & SECC, 2011 \\
\hline & Share of Casual Manual Labour & Sahana et al., 2020 & SECC, 2011 \\
\hline & HHs Income less than 5000 ₹ & Panthil et al., 2015 & SECC, 2011 \\
\hline \multirow[t]{4}{*}{ Assets compo-sition } & HHs Access to Banking Facility & Islam and Hasan, 2015 & HLPCA, 2011 \\
\hline & HHs Having CNG Connection & Motsholapheko er & HLPCA, 2011 \\
\hline & HHs having Mobile \& Landline Connection & Sahana et al., 2020 & HLPCA, 2011 \\
\hline & HHs Having Two/ Four Wheeler & Sahana et al., 2020 & HLPCA, 2011 \\
\hline
\end{tabular}

a sort of multivariate examination used to frame another variable from a bunch of factors with the end goal that the new factor contains the greater part of the inconstancy of the SECC information (2011), lastly we need to ascertain the degree of. The objective of performing PCA is to incorporate an expansive understanding of the information by gathering like-factors into segments inside the more noteworthy number of investigation factors that enough record for fluctuation (Hummell et al. 2016). The examination further empowers the comprehension of part gatherings and gain understandings as more investigations break down the outcomes. Kaiser standardization and Varimax methods were utilized as extraction strategies for materials, following techniques presented by Abdi and Williams (2010). To show the inactive factors, just segments with eigenvalues more noteworthy than 1.5 were separated and called. Cardinality ( \pm ) was called and doled out to each factor. To arrive at the all-out DSoBI, the DSoBI was dictated by adding the scores of each part. For each spatial unit, our refreshed DSoBI for towns under Kakdwip sub-division was determined (202 towns) by adding the essential segment values:
$\mathrm{DSoBI}_{\text {village }}=\mathrm{PC}_{1}+\mathrm{PC}_{2}+\mathrm{PC}_{3}+\mathrm{PC}_{4}+\mathrm{PC}_{5}$

where, $\mathrm{PC}_{1}$ is the resulted value of multiplication of variance of $\mathrm{PC}_{1}$ and weighted index value of $\mathrm{PC}_{1}$. The resulted values of principal component values of 1 to 5 have been mapped using ArcGIS version 10.3 and overall backwardness has been estimated by making summation of all PC values. After develop the PC values, mean and standard deviation has been calculated. Overall backwardness and individual PC values have been classified as very low (< mean - 1SD), low (mean to mean - 1SD), moderate (mean to $1 \mathrm{SD}+$ mean $)$, high $(>$ mean $+1 \mathrm{SD})$ categories. From the resulted value as estimation done based on simple quotient method, higher values explain lower backwardness and vice-versa.

\section{Multivariate-ordinal logistic regression}

Ordinal logistic regression (also known as 'ordinal regression') is a technique for predicting an ordinal dependent variable from a set of independent factors. When the 
Fig. 3 Flow chart showing methodological framework of the study

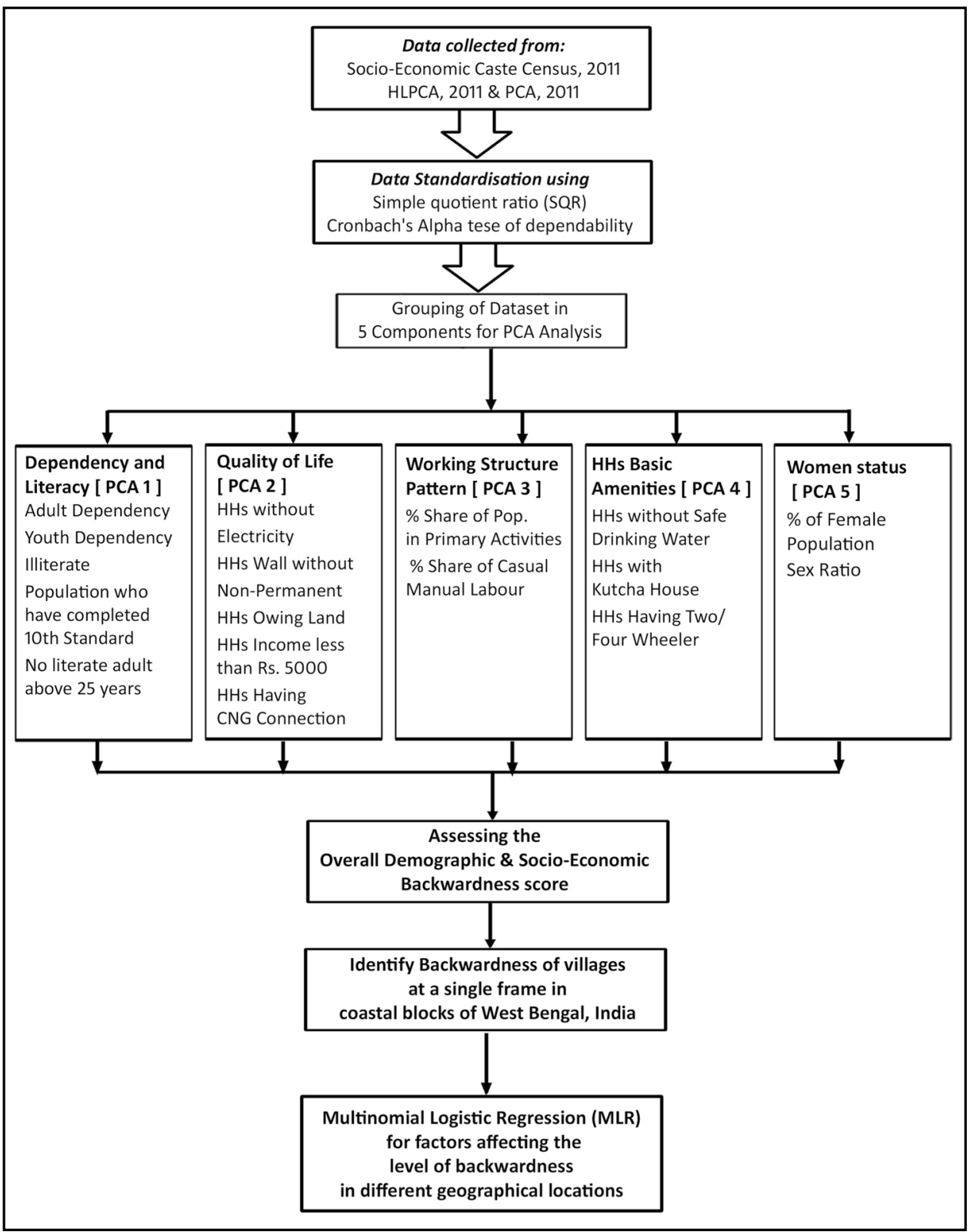

resulted variable is polychotomous, it can happen in a variety of ways. Multinomial and ordinal outcome variables are two types of outcome variables (Fahrmeir and Lang 2001; Rasheed et al., 2016). The multinomial logistic regression model cannot be used when the dependent variable is categorized by order of magnitude. For assessing ordinal response variables, a number of logistic regression models have been created. Furthermore, when numerous factors must be taken into account, special multivariate analysis for ordinal data is the natural choice (Rutstein 2000). In this study multivariate-ordinal logistic regression has been done to find out the factors responsible of backwardness in different geographical locations.

\section{Results}

\section{Classification of villages based on backwardness score}

Communalities of the variables shown in Table 3 have been extended using PCA and selected indicators shown in Table 2. PCA has been done based on the resulted eigen values and component score to find out each PCA value (PCA 1 to PCA 5) and summation done to find out the nature of backwardness using equation 1 . The component score of each variance explaining more than 0.5 have been taken into consideration for developing the each PCA 
aggregate score. Using the equation 2, the resulted values have been categorized into four backward classes, i.e. low, moderate, high and very high based on mean and standard deviation values from each PCA. After having the result of each PCA (PCA 1 to PCA 5), overall backwardness has been estimated making the average values from all PCA and categorized into four backward classes (Fig. 4a-e).

The results of overall backwardness index value ranges from -0.436 to 12.329 with average value of 3.616 and 1.786 as standard deviation. Very high degree of backwardness ( $<$ 1.83 ) in respect of demographic and socio-economic indicators have been found among 24 villages which is nearly $11.8 \%$ of the study area. These highly backward village mostly positioned in Sagar (12 villages) and Pathar Pratima (7 villages) in a large number (Fig. 5). As the Fig. 5 make a straight forward indication of village level backwardness; individual groups; i.e. demography and literacy in PCA 1, quality of life in PCA 2, working structure pattern in PCA 3 , household basic amenities in PCA 4 and women status in PCA 5 give a clear idea of the villages in the PCA scores respectively stated in Table 3. PCA 1, PCA 3 and PCA 4 depicted a higher degree of backwardness for the resulted villages which improvised the overall backwardness in a large scale. When geographical location has been taken into consideration; out of 24 villages, 9 villages located in riverine/ estuarine condition when 15 from inland category. Except Sagar and Pathar Pratima blocks, 5 other villages that fall under very high backwardness category located in Namkhana and Kakdwip blocks Table 4.

The next vulnerable group has been designated 'high,' with index values ranging from 1.83 to 3.62 , and 93 villages ( $46 \%$ of the total study villages) fall into this category. This category depicts the research area's highest concentration of communities. Nearly a quarter of the villages (50 out of 202) had a high level of backwardness found in the riverine/ estuarine, coastal front and island locations. The Namkhana and Sagar blocks, respectively, have 19 and 17 villages that fall into the high backwardness category. When it comes to geographical location, 62 (almost $33 \%$ ) of the villages with a high level of backwardness are found along the riverine/ estuarine condition. On the other side, 8 of the 12 coastal front and Island villages fell into this category, with the majority of them located in the Sagar (3), Pathar Pratima (3), and Namkhana (2) blocks. In the research region, 70 villages $(34.65 \%)$ are classified as somewhat backward with values range from 3.62 to 5.40 (Table 5). These villages are mostly found in Kakdwip (21) and Pathar Pratima (27) in the study area's northern region. Surprisingly, $45(64.28 \%)$ of the 70 moderately backward villages are located in a riverine/ estuary environment (Table 6). In the research region, 15 (7.43 $\%$ ) villages had a low level of backwardness (index value above 5.40). These villages are primarily found in the Kakdwip (8) and Pathar Pratima (5) blocks' northernmost areas.
Surprisingly, no coastal villages fall into this group, while inland communities have a higher degree of demographic and socioeconomic backwardness (see Supplementary Sheet for Detail Results).

\section{Backwardness in a single frame and reflect the level of backwardness among the villages in different geographical locations}

Table 7 and Fig. 6 depict seven villages classified as category 1 and located in three C.D. Blocks, namely Sagar (2), Namkhana (2), and Pathar Pratima (3). In category 1, villages located along a river or in an estuarine location, indicating susceptibility to multi-hazard effects in this region. In addition, Fig. 6 shows 58 villages in category 2 and 74 villages in category 3 . Pathar Pratima block has the majority of category 2 villages, while Sagar has a higher proportion of category 3 villages (Table 7). Pathar Pratima, Sagar, and Kakdwip blocks make up the majority of the village under category 3. Nearly 36.6 percent of villages in category 3 are located in riverine/ estuary areas (48 out of 74 ). When category 4 and 5 villages are considered, 57 and 6 villages are discovered, indicating the nature of underdevelopment and severely asymmetrical backwardness that exists in this deltaic region of West Bengal. This research also reveals the nature of the backwardness hierarchy in the study area (Mondal et al., 2021; Sahana et al., 2019).

With 18 inland villages, 43 riverine/ estuary villages, two coastal front villages, and two island villages, 65 villages (32.2\%) fall into this high to extremely high backwardness category. The overall value for backwardness is 2.64 (Table 8) and depicts the population share of total population $(35.34 \%)$ and female population share $(34.61 \%)$ in this extremely vulnerable position. The majority of households $(88.81 \%)$ in this group do not have access to safe drinking water, which is the most concerning aspect of the study. This scenario also exposes a large portion of the elderly population $(35.09 \%)$. A multinomial logistic regression analysis was performed for a better approach to policy planning, allowing the proper focus to be taken into consideration to minimise the evil effect in this study region.

\section{Factors affecting the level of backwardness in different geographical locations}

In this portion, we are going to examine of selected demographic and socio-economic backwardness indicators affecting the level of overall backwardness in inland and riverine/ estuarine locations using multinomial logistic regression (MLR). Here coastal front and Island villages have not taking into account as the response is very low in number (only 4 among 65 villages in this group). The dependent variable, 'overall backwardness' has been 


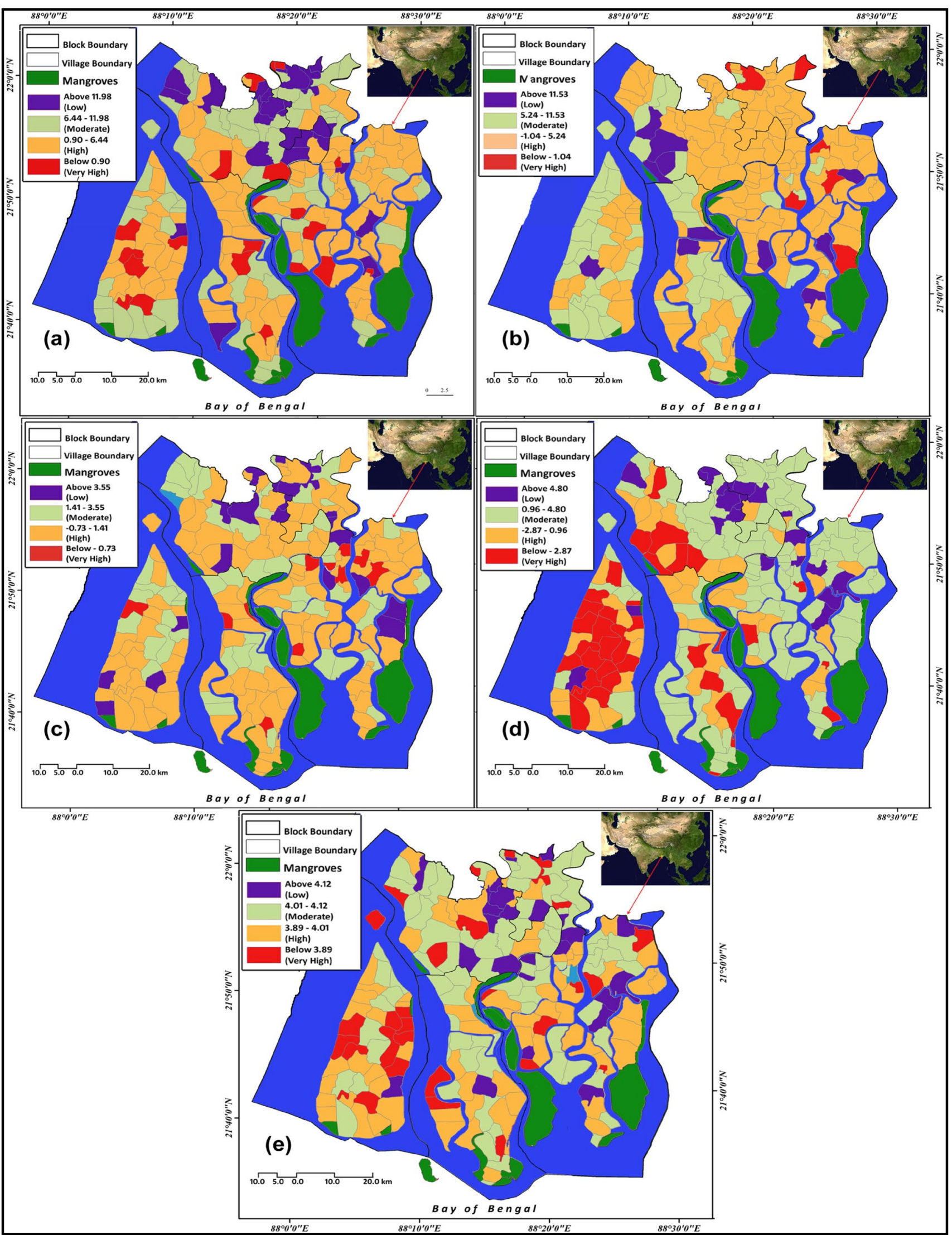


४Fig. 4 Geographic distribution of principal component values $[(\mathbf{a})$ PCA1: Degree of Dependency, (b) PCA2: Quality of Life, (c) PCA3: Working Structure, (d) PCA4: Households Basic Amenities and (e) PCA5: Status of Women] for assessing the demographic and socioeconomic backwardness at micro level in coastal West Bengal, India

coded as mild to moderate $=0$ and severe $=1$. The predictors in the model include share of the female population ('femaleID' coded $0=<40 \%, 1=>40 \%$ ), share of $0-6$ years population ('childID' coded $0=<10 \%, 1=10-15 \%, 2=15$ $20 \%$ and $4=20 \%$ ), households without land ('landID' coded $0=<40 \%, 1=40-60 \%$ and $2=>60 \%$ ), Share of HHs without safe drinking water ('waterID' coded $0=<50 \%, 1=>50 \%$ ), share of households income less than 5000 ₹ ('incomeID' coded $0=<75 \%, 1=50-75 \%$ and $2=<50 \%$ ) and lastly share of households without banking ('bankID' coded $0=>50 \%, 1=$ $<50 \%$ ). Although ordinal logistic regression is a reasonable approach to use with our data given the dummy variable may be considered ordered categorical, here we found that the proportional odds assumption would be violated during preliminary analysis. As a result, Multinomial Logistic Regression (MLR) approach has been taken for further analysis.

This portion of the output contains the results from a likelihood ratio-chi-square test (Table 9); comparing the fit of the model with the complete set of predictors with an intercept-only, or null, model (no predictors). If significant, it can infer that at least one population regression slope is significantly different from zero. On the basis of logistic regression test, it can analyses that model containing the full set of predictors represents a significant improvement in fit to a null model $\left[\mathrm{LR} \chi^{2}(72)=94.438, \mathrm{p}<0.005\right]$. From this analysis it can easily be predicted that at least one population slope is non-zero.

The portion of the output contains pseudo R-square indices (Table 10). These indices are not computed in the same way as R-square in OLS regression. As a result, one cannot interpret the result as proportion of variance accounted for as in the context of OLS regression. Based on the Pituch and Stevens (2015), MaFadden Pseudo R-square formed the ratio of the difference in model deviances for the null and full models to the model deviance to the null model. Based on MaFadden Pseudo R-square result, it can be infer that, the model containing our predictors represents a $4.4 \%$ improvement in fit relative to the null model. There are additional chi-square goodness of fit test has been done to validate the model. When non-significant, it provides evidences for a well-fitting model. The results of this test do not always necessarily agree, as we can see from the Table 11. The Pearson chi-square test suggests a fitting model $(\mathrm{p}=0.432)$, whereas the Deviance chi-square suggests the opposite $(\mathrm{p}=0.031)$.

This portion of the output gives an indication of how the model is performing is correct predicting category membership on Dependent Variable (DV). The classification accuracy for a given category has been reflected in the row percentages. For an example, the model correctly predicted backwardness falling into the 'riverine/estuarine' locations of backward group at a rate of $43 /(4+43+18) * 100=$ $66.16 \%$. The model also correctly predicted backwardness falling into the 'inland' at a rate of $18 /(4+43+18) * 100=$ $27.69 \%$ whereas falling into the 'coastal front' level of backwardness group at a rate of $4 /(4+43+18) * 100=9.23 \%$ not critically explain. The overall classification accuracy for the model found as $50.87 \%$ and it is clearly shows that the model performed terribly well in predicting the 'riverine/estuarine' level of backwardness group (Table 11). However, it performs well when it comes to predicting group membership across the three levels of taken geographical location levels.

The likelihood ratio chi-square tests can be considered omnibus tests of the effect of VI in the model. In terms of significant predictors, female share, owing land, water availability and income found statistically significant.

Now we are going to take a look our regression Table 12 showing the parameter estimates. The first section allows us to determine which of the independent variables significantly predict whether a village backwardness fall into the riverine/ estuarine category to inland category. The 'female' share in backwardness predictor for riverine/ estuarine condition, predictor is positive and significant $(b=1.019$, s.e. $=0.887, \mathrm{p}=.000$ ). Formally speaking, the regression slope for 'female' can be interpreted as follows: 'for each unit increase on this variable, the log-odds of a case falling into riverine/ estuarine condition is predicted to increase by 1.017 units (Table 12). The odd ratio is 19.212 , indicating that with increasing scores on this predictor, the odds of falling into the riverine/ estuarine condition as changing by 18.522 . Here, the $\operatorname{Exp}(\mathrm{B})$ is referred to as an odds ratio. From the first section, owing land, water availability and income of the households are found positive and significant $(b=-1.523$, s.e. $=1.290, p=.001 ; b=-1.222$, s.e. $=2.287, p=$ .001 and $\mathrm{b}=-1.872$, s.e. $=1.311, \mathrm{p}=.000-1)$ also in riverine/ estuarine condition. We can analyses the backwardness level with its predictors from the second portion in a same manner for inland villages (Table 13).

\section{Discussions}

The situation criteria of indicators for develop and assess the scenario of demographic and socio-economic backwardness in deltaic region is an important task (Singh 2006; Abid et al. 2015). Participatory approach, field investigation in pre and post hazard time (basically as this study region experienced under multi-hazards susceptibility) along with literature survey give a clear idea to develop the methodology along with indicators selection. Before handling the data for PCA, 25 indicators have been estimated using Cronbach's 
Table 2 Descriptive statistics of selected variables

\begin{tabular}{|c|c|c|c|c|c|c|c|}
\hline Variables & Min. & Max. & Mean & St. Dev. & Skewness & Kurtosis & $\begin{array}{l}\text { Cron- } \\
\text { bach's } \\
\text { Alpha }\end{array}$ \\
\hline Adult Dependency & 2.52 & 9.13 & 4.49 & 0.87 & 0.90 & 4.71 & 0.79 \\
\hline Youth Dependency & 23.77 & 44.70 & 29.88 & 3.43 & 1.62 & 4.02 & 0.63 \\
\hline Female Population & 38.27 & 50.23 & 48.25 & 1.29 & -4.16 & 35.40 & 0.77 \\
\hline Sex ratio & 744 & 1013 & 935 & 35.80 & -1.32 & 5.79 & 0.67 \\
\hline HHs without Electricity & 0.00 & 71.60 & 12.79 & 17.29 & 1.45 & 1.42 & 0.69 \\
\hline HHs without Safe Drinking Water Facility & 1.10 & 100.00 & 93.10 & 16.73 & -3.83 & 16.73 & 0.62 \\
\hline HHs without Sanitation & 0.00 & 96.20 & 35.13 & 22.48 & 0.47 & -0.44 & 0.72 \\
\hline HHs with Kutcha House & 27.10 & 100.00 & 63.87 & 14.48 & -0.20 & 0.17 & 0.70 \\
\hline HHs Wall without Non-Permanent Structures & 0.00 & 100.00 & 81.03 & 11.29 & -3.40 & 23.55 & 0.78 \\
\hline Illiterate & 3.04 & 85.63 & 24.94 & 11.08 & 2.40 & 10.14 & 0.71 \\
\hline Population who have completed $10^{\text {th }}$ Standard & 0.85 & 13.97 & 7.27 & 2.24 & -0.03 & 1.05 & 0.67 \\
\hline No literate adult above 25 years & 0.43 & 13.64 & 3.72 & 2.17 & 1.74 & 4.68 & 0.61 \\
\hline HHs Owing Land & 9.14 & 83.64 & 41.29 & 15.00 & 0.03 & 0.03 & 0.66 \\
\hline Share of Population in Primary Activities & 1.49 & 94.01 & 20.37 & 15.72 & 2.22 & 6.99 & 0.72 \\
\hline Share of Casual Manual Labour & 2.07 & 95.55 & 64.80 & 16.73 & -1.35 & 2.74 & 0.71 \\
\hline HHs Income less than 5000 ₹ & 57.25 & 99.27 & 90.45 & 7.35 & -1.56 & 3.39 & 0.69 \\
\hline HHs Having CNG Connection & 0.00 & 19.40 & 0.71 & 2.46 & 6.66 & 52.33 & 0.65 \\
\hline HHs Having Two/ Four Wheeler & 0.00 & 17.50 & 3.25 & 3.25 & 1.93 & 4.53 & 0.68 \\
\hline
\end{tabular}

Table 3 Descriptive statistics of selected variables

\begin{tabular}{|c|c|c|c|c|c|c|c|}
\hline \multirow[t]{2}{*}{ Group of Indicators } & \multirow[t]{2}{*}{ Variables } & \multicolumn{5}{|c|}{ Component } & \multirow{2}{*}{$\begin{array}{l}\text { Weighted } \\
\text { Variance } \\
\text { Score }\end{array}$} \\
\hline & & 1 & 2 & 3 & 4 & 5 & \\
\hline \multirow[t]{5}{*}{ Dependency and Literacy } & Adult Dependency & -0.704 & -0.016 & -0.123 & 0.092 & 0.039 & -3.51 \\
\hline & Youth Dependency & 0.791 & 0.203 & 0.197 & 0.022 & 0.144 & 5.10 \\
\hline & Illiterate & 0.841 & 0.035 & -0.178 & 0.231 & 0.041 & 4.28 \\
\hline & Population who have completed $10^{\text {th }}$ & -0.726 & -0.039 & -0.075 & 0.015 & -0.114 & -3.94 \\
\hline & No literate adult above 25 years & 0.833 & 0.085 & -0.132 & 0.210 & 0.082 & 4.51 \\
\hline \multirow[t]{5}{*}{ Qualityof Life } & HHs without Electricity & -0.046 & -0.632 & -0.074 & 0.171 & 0.131 & -1.60 \\
\hline & HHs Wall without Non-Permanent & 0.098 & 0.671 & -0.116 & 0.114 & -0.045 & 2.21 \\
\hline & HHs Owing Land & 0.312 & -0.556 & 0.042 & -0.073 & 0.070 & 0.05 \\
\hline & HHs Income less than & 0.096 & 0.566 & 0.230 & 0.184 & -0.028 & 2.85 \\
\hline & HHs Having CNG Connection & 0.011 & -0.780 & 0.050 & -0.144 & -0.026 & -2.28 \\
\hline \multirow[t]{2}{*}{ Working Structure Pattern } & $\%$ Share of Population in Primary Activities & 0.015 & 0.215 & -0.91 & 0.032 & -0.056 & -1.41 \\
\hline & $\%$ Share of Casual Manual Labour & 0.011 & 0.118 & 0.932 & 0.113 & 0.087 & 2.82 \\
\hline \multirow[t]{3}{*}{ HHs Basic Amenities } & HHs without Safe Drinking Water & 0.208 & 0.07 & -0.121 & 0.557 & 0.119 & 2.17 \\
\hline & HHs with Kutcha House & 0.023 & 0.004 & 0.061 & 0.78 & 0.065 & 1.84 \\
\hline & HHs Having Two/ Four Wheeler & -0.097 & -0.269 & -0.124 & -0.677 & -0.185 & -3.05 \\
\hline \multirow[t]{2}{*}{ Women status } & $\%$ of Female Population & 0.095 & -0.059 & 0.064 & 0.102 & 0.961 & 2.04 \\
\hline & Sex Ratio & 0.105 & -0.063 & 0.08 & 0.121 & 0.959 & 2.15 \\
\hline Variance explained & & 18.92 & 15.24 & 13.85 & 11.21 & 10.093 & \\
\hline Cumulative variance explained & & 18.92 & 34.16 & 48.01 & 59.22 & 69.313 & \\
\hline
\end{tabular}


Fig. 5 Geographic distribution of overall demographic and socio-economic backwardness at micro level in four coastal blocks of West Bengal, India
Table 4 Level of backwardness in the villages located in different Administrative Unitwise of the Study Area

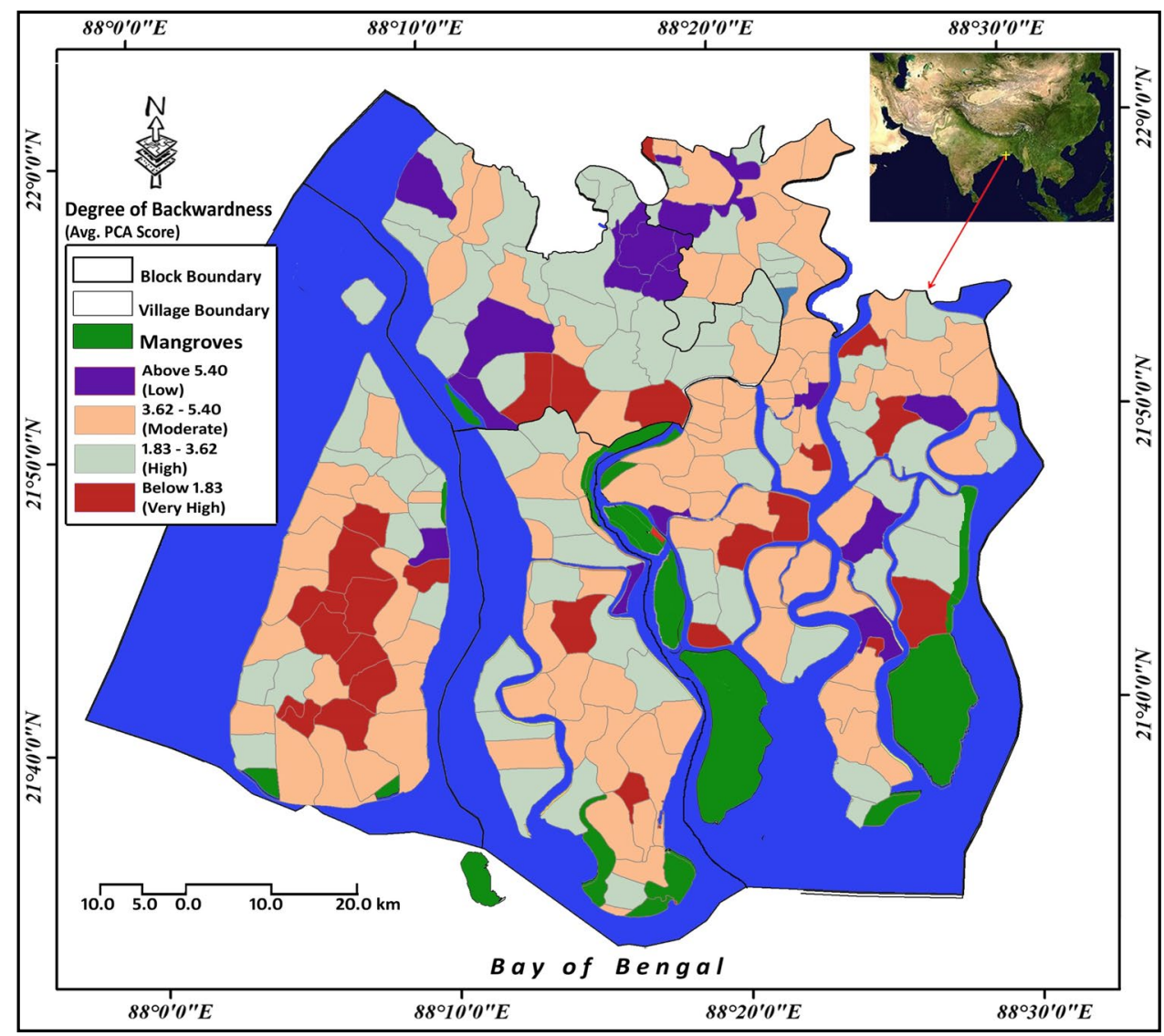

\begin{tabular}{|c|c|c|c|c|c|c|c|c|}
\hline \multirow[t]{2}{*}{ Backwardness } & \multicolumn{2}{|l|}{ Low } & \multicolumn{2}{|c|}{ Moderate } & \multicolumn{2}{|c|}{ High } & \multicolumn{2}{|c|}{ Very High } \\
\hline & Act. & in $\%$ & Act. & in $\%$ & Act. & in $\%$ & Act. & in $\%$ \\
\hline Kakdwip & 8 & 3.96 & 21 & 10.40 & 7 & 3.47 & 3 & 1.49 \\
\hline Namkhana & 1 & 0.50 & 12 & 5.94 & 19 & 9.41 & 2 & 0.99 \\
\hline Pathar Pratima & 5 & 2.48 & 27 & 13.37 & 50 & 24.75 & 7 & 3.47 \\
\hline Sagar & 1 & 0.50 & 10 & 4.95 & 17 & 8.42 & 12 & 5.94 \\
\hline Overall & 15 & 7.43 & 70 & 34.65 & 93 & 46.04 & 24 & 11.88 \\
\hline
\end{tabular}

\begin{tabular}{|c|c|c|c|c|c|c|c|c|}
\hline \multirow[t]{2}{*}{ Backwardness } & \multicolumn{2}{|l|}{ Low } & \multicolumn{2}{|c|}{ Moderate } & \multicolumn{2}{|c|}{ High } & \multicolumn{2}{|c|}{ Very High } \\
\hline & Act. & in $\%$ & Act. & in $\%$ & Act. & in $\%$ & Act. & in $\%$ \\
\hline PCA 1 & 23 & 11.39 & 65 & 32.18 & 96 & 47.52 & 18 & 8.91 \\
\hline PCA 2 & 11 & 5.45 & 53 & 26.24 & 131 & 64.85 & 7 & 3.47 \\
\hline PCA 3 & 24 & 11.88 & 55 & 27.23 & 111 & 54.95 & 12 & 5.94 \\
\hline PCA 4 & 18 & 8.91 & 108 & 53.47 & 40 & 19.80 & 36 & 17.82 \\
\hline PCA 5 & 25 & 12.38 & 79 & 39.11 & 73 & 36.14 & 25 & 12.38 \\
\hline Overall & 15 & 7.43 & 70 & 34.65 & 93 & 46.04 & 24 & 11.88 \\
\hline
\end{tabular}

Table 5 Level of Demographic and Socio-economic Backwardness in the villages located in different Geographical Locations of the Study Area location, the villages have been categorized into three characters; i.e., inland villages $(31.18 \%)$, riverine/ estuarine villages $(59.41 \%)$, coastal front villages $(5.94 \%)$ and island villages $(3.46 \%)$. to make better understand the nature of
Alpha to make reliability of the dataset used for assessing backwardness of the study region at micro level (village as a unit). Kakdwip sub-division controls over four C.D. Block which have 202 villages. According to its geographical 
Table 6 Level of Development in the villages located in different Geographical Locations and Administrative Unit-wise of the Study Area

\begin{tabular}{|c|c|c|c|c|c|c|c|c|c|}
\hline \multirow[t]{2}{*}{ Backwardness } & \multirow[t]{2}{*}{ Geographical Location } & \multicolumn{2}{|l|}{ Low } & \multicolumn{2}{|c|}{ Moderate } & \multicolumn{2}{|l|}{ High } & \multicolumn{2}{|c|}{ Very High } \\
\hline & & Act. & in $\%$ & Act. & in $\%$ & Act. & in $\%$ & Act. & in $\%$ \\
\hline \multirow{4}{*}{$\begin{array}{l}\text { Dependency and Literacy } \\
(P C A 1)\end{array}$} & Island & 1 & 0.50 & 3 & 1.48 & 3 & 1.488 & 0 & 0.00 \\
\hline & Coastal front & 0 & 0.00 & 8 & 3.96 & 4 & 1.98 & 0 & 0.00 \\
\hline & Riverine/ Estuarine & 11 & 5.45 & 39 & 19.34 & 65 & 32.24 & 5 & 2.48 \\
\hline & Inland & 11 & 5.45 & 15 & 7.43 & 24 & 11.88 & 13 & 6.44 \\
\hline \multirow{4}{*}{$\begin{array}{l}\text { Quality } \\
\text { of Life } \\
(P C A 2)\end{array}$} & Island & 0 & 0.00 & 2 & 0.99 & 5 & 2.48 & 0 & 0.00 \\
\hline & Coastal front & 2 & 0.99 & 5 & 2.48 & 4 & 1.98 & 0 & 0.00 \\
\hline & Riverine/ Estuarine & 6 & 2.97 & 29 & 14.38 & 81 & 40.17 & 4 & 1.98 \\
\hline & Inland & 3 & 1.49 & 17 & 8.42 & 40 & 19.80 & 3 & 1.49 \\
\hline \multirow{4}{*}{$\begin{array}{l}\text { Working Structure } \\
(P C A 3)\end{array}$} & Island & 0 & 0.00 & 3 & 1.48 & 4 & 1.98 & 0 & 0.00 \\
\hline & Coastal front & 1 & 0.50 & 0 & 0.00 & 11 & 5.45 & 0 & 0.00 \\
\hline & Riverine/ Estuarine & 12 & 5.94 & 30 & 14.88 & 33.23 & 34.65 & 11 & 5.45 \\
\hline & Inland & 11 & 5.45 & 22 & 10.89 & 29 & 14.36 & 1 & 0.50 \\
\hline \multirow[t]{4}{*}{ HHs Basic Amenities } & Island & 0 & 0.00 & 7 & 3.47 & 0 & 0.00 & 0 & 0.00 \\
\hline & Coastal front & 0 & 0.00 & 6 & 2.97 & 4 & 1.98 & 2 & 0.99 \\
\hline & Riverine/ Estuarine & 9 & 4.46 & 65 & 32.24 & 28 & 13.86 & 18 & 8.91 \\
\hline & Inland & 9 & 4.46 & 30 & 14.85 & 8 & 3.96 & 16 & 7.92 \\
\hline \multirow{4}{*}{$\begin{array}{l}\text { Status of Women } \\
(P C A 4)\end{array}$} & Island & 0 & 0.00 & 0 & 0.00 & 4 & 1.98 & 3 & 1.48 \\
\hline & Coastal front & 1 & 0.50 & 2 & 0.99 & 11 & 5.45 & 0 & 0.00 \\
\hline & Riverine/ Estuarine & 17 & 8.42 & 47 & 23.27 & 43 & 21.33 & 11 & 5.46 \\
\hline & Inland & 7 & 3.47 & 30 & 14.85 & 15 & 7.43 & 11 & 5.45 \\
\hline \multirow{4}{*}{$\begin{array}{l}\text { Overall } \\
(P C A \text { Avg.) }\end{array}$} & Island & 0 & 0.00 & 2 & 0.99 & 5 & 2.48 & 0 & 0.00 \\
\hline & Coastal front & 0 & 0.00 & 5 & 2.48 & 7 & 3.47 & 0 & 0.00 \\
\hline & Riverine/ Estuarine & 7 & 3.47 & 45 & 22.32 & 62 & 30.75 & 9 & 4.46 \\
\hline & Inland & 8 & 3.96 & 18 & 8.91 & 19 & 9.41 & 15 & 7.43 \\
\hline
\end{tabular}

backwardness in light of geographical locations (Paul et al. 2021). In contrast to Chang et al. (2015) and Bergstrand et al. (2015), this study has been characterized along with specific indicators of social vulnerability and hence in this study researchers follow the selection criteria as given by Islam and Hasan (2015), Emmanuel et al. (2017) and Basu and Das (2020).

A wide range of factors make an impact for the backwardness in this deltaic part of West Bengal. Cyclone induced multi-hazards, like, inundation, salt water intrusion in agricultural area and pisiculture land, breaching of embankment and overall anthropogenic control over landuse regulation make the area more susceptible for such backwardness. Cyclones like Aila in 2009, Bulbul in 2019, Amphan in 2020 and more recently Yaas in 2021 compelled the population to change their livelihood approach. Loss in agricultural production and fishing activities due to such hydro-meteorological hazards has been forcibly change the quality of life among the dwellers of this deltaic part. From 2011, socio-economic caste census, India; it has been clearly figured out that, nearly $80 \%$ of the villages households are in deprived condition in various form of life (Paul et al., 2020). Accessibility to safe drinking water, safe and neat hygiene for women, overall sanitation situation are beyond imagination. The situations become more worsen after any cyclonic storms pass through this deltaic are (see Plate 1). Huge amount of out-migration took place after cyclone Aila (2009) figured out from door-to-door survey and the percentage of out-migrated population returned back during 2016-17 period. But cyclone Amphan in 2020 make the situation as it was in 2009. This year, cyclonic landfall of Yaas (in May 2021) aggravates the situation more defenceless where the current pandemic (Covid-19) make a helpless situation in addition. The economic features of households (i.e. Households monthly income less than 5000 ₹) in the study region causing more deterioration which need to be address by the stakeholders of the society. Overall literacy gap among the male-female and literacy level of the female population make more reluctant to address the real ground situation.

Bakshi et al. (2015) and Basu and Das (2020) have tried to frame backwardness at district level for Indian states where as NITI Aayog in 2017 also developed the methodology to addressed the backwardness and evaluated 115 districts as backward applying 11 indicators. Hence in this research, we have tried to develop the level of demographic and socio-economic backwardness taking the high and very high PCA values (taking PCA 1 to PCA 5) for framing the 
Table 7 Category-wise Level of Demographic and Socio-economic Backwardness of villages located in different Administrative and Geographical Locations of the Study Area

\begin{tabular}{|c|c|c|c|c|c|c|}
\hline \multirow[t]{2}{*}{ Administrative Units } & \multirow[t]{2}{*}{ Geographical Location } & \multicolumn{5}{|c|}{ Category-wise level of demographic and socio-economic backwardness } \\
\hline & & $\begin{array}{l}\text { Category } \\
1\end{array}$ & $\begin{array}{l}\text { Category } \\
2\end{array}$ & $\begin{array}{l}\text { Category } \\
3\end{array}$ & $\begin{array}{l}\text { Category } \\
4\end{array}$ & $\begin{array}{l}\text { Category } \\
5\end{array}$ \\
\hline \multirow[t]{4}{*}{ Kakdwip } & Island & 0 & 0 & 0 & 0 & 0 \\
\hline & Coastal front & 0 & 0 & 0 & 0 & 0 \\
\hline & Riverine/ Estuarine & 0 & 3 & 11 & 7 & 1 \\
\hline & Inland & 0 & 2 & 5 & 7 & 3 \\
\hline \multirow[t]{4}{*}{ Namkhana } & Island & 0 & 1 & 3 & 0 & 0 \\
\hline & Coastal front & 0 & 1 & 1 & 0 & 0 \\
\hline & Riverine/ Estuarine & 2 & 5 & 6 & 6 & 0 \\
\hline & Inland & 0 & 4 & 1 & 6 & 0 \\
\hline \multirow{4}{*}{$\begin{array}{l}\text { Pathar } \\
\text { Pratima }\end{array}$} & Island & 0 & 1 & 0 & 1 & 0 \\
\hline & Coastal front & 0 & 1 & 4 & 1 & 0 \\
\hline & Riverine/ Estuarine & 3 & 22 & 17 & 14 & 1 \\
\hline & Inland & 0 & 10 & 5 & 4 & 1 \\
\hline \multirow[t]{4}{*}{ Sagar } & Island & 0 & 0 & 1 & 0 & 0 \\
\hline & Coastal front & 0 & 0 & 3 & 1 & 0 \\
\hline & Riverine/ Estuarine & 2 & 6 & 14 & 7 & 0 \\
\hline & Inland & 0 & 2 & 3 & 3 & 0 \\
\hline \multirow[t]{4}{*}{ Overall } & Island & 0 & 2 & 4 & 1 & 0 \\
\hline & Coastal front & 0 & 2 & 8 & 2 & 0 \\
\hline & Riverine/ Estuarine & 7 & 36 & 48 & 34 & 2 \\
\hline & Inland & 0 & 18 & 14 & 20 & 4 \\
\hline Total Villages & & $7(3.5 \%)$ & $58(28.7 \%)$ & $74(36.6 \%)$ & $57(28.2 \%)$ & $6(2.9 \%)$ \\
\hline
\end{tabular}

degree of backwardness in a single frame. Here 5 categories have been considered to classify the degree of backwardness. Very high as Category 1 (village resulting high to very high in all 5 PCA results), high as Category 2 (village resulting high to very high in at least 4 PCA results), moderate as Category 3 (village resulting high to very high in at least 3 PCA results), low as Category 4 (village resulting high to very high in at least 2 PCA results) and very low as Category 5 (village resulting high to very high in at least 1 PCA result). The characteristics of categories 1 and 2 are depicted in this analysis from numerous demographic and socioeconomic perspectives. This category has also been summarised by geographic region to assist policymakers in comprehending the importance of policy proposals in a variety of areas.

The empirical research applying multinomial logistic regression (MLR) examined the level of backwardness among the villages located in riverine/ estuarine and inland locations in deltaic part of West Bengal, India in light multihazards perspective occurred several times in the region. Based on the research findings, Kakdwip and Namkhana comprises with only $12.82 \%$ and $11.76 \%$ of villages respectively whereas Sagar and Pathar Pratima accounts 55\% and $40.46 \%$ villages respectively in high to very categories. The level of backwardness found much higher in riverine/ estuarine (2.88) condition to coastal front (2.64) and inland (2.45) conditions. Basically female population, child population, household owing agricultural land and income level show clear picture of backwardness in this region for both locations (riverine/ estuarine and inland) which also make an similar way findings to Dubey et al. (2020).

\section{Conclusions and Policy Recommendation}

Areas under coast are sensitive to both development pressures and consequences to hydro-meteorological extreme events, exposing dwellers and ecosystems to the results of climate change (Satapathy et al. 2014; Krishnan et al. 2018). Devastating cyclones in recent past due to climate change in India make much more exposed and lethal along the coast. As vulnerability does not always static, it is most significant to institutionalize mutual interest on the geographic unit level, wherein planners and policy makers can take the right decision enhancing the profile of indicators. The present research delivers an outline to assess the backwardness in demographic and socio-economic perspective at micro level (village as a unit) which could assistance in reckoning the maximum susceptible areas for prioritized consideration 
Fig. 6 Backwardness of villages at a single frame in coastal blocks of West Bengal, India

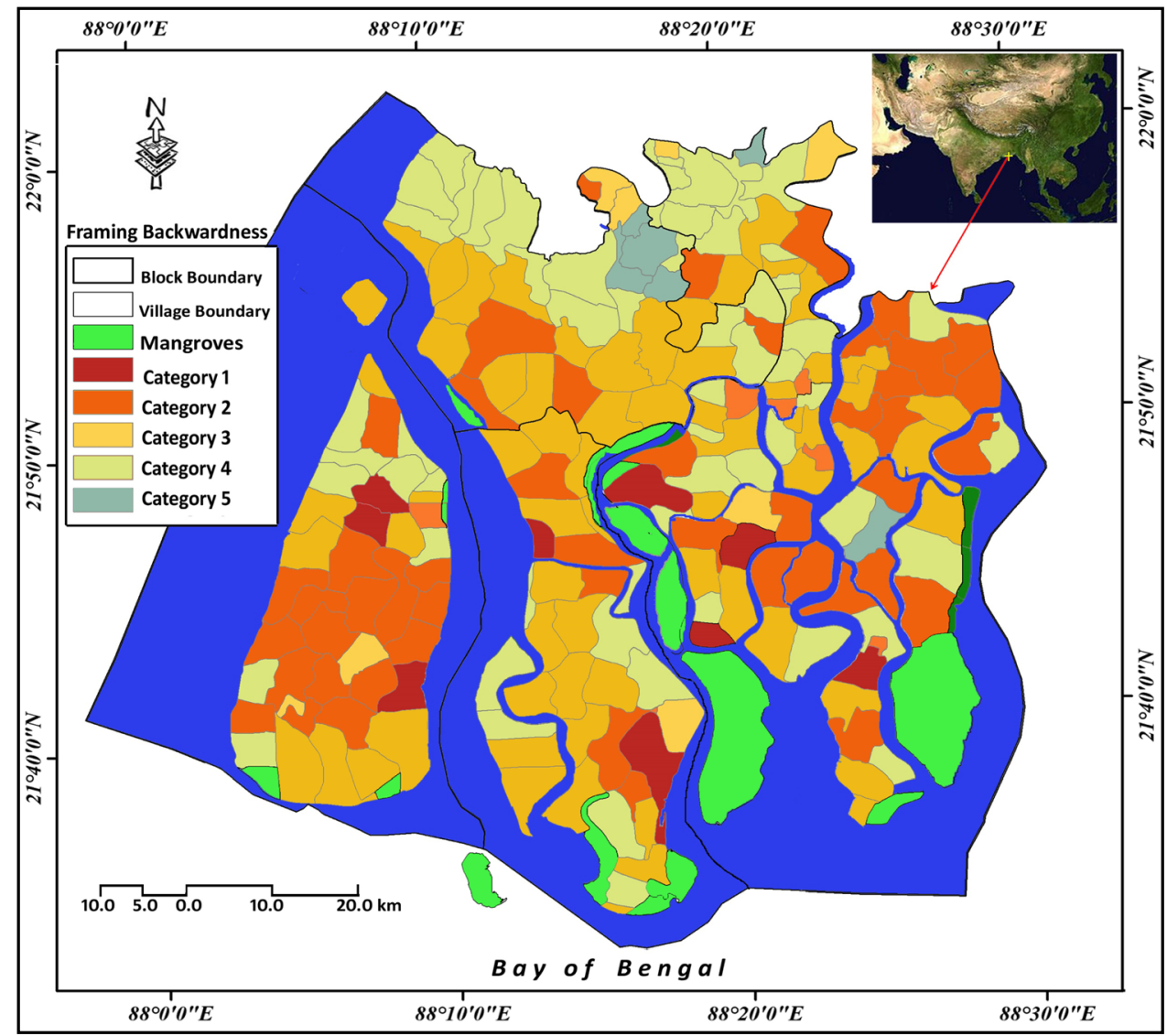

Table 8 selected demographic and socio-economic perspective under category 1 and 2 in respect of geographical locations

\begin{tabular}{|c|c|c|c|c|c|c|}
\hline $\begin{array}{l}\text { Geographical Loca- } \\
\text { tion }\end{array}$ & $\begin{array}{l}\text { Overall Backward- } \\
\text { ness }\end{array}$ & Total population & $\%$ of $\mathrm{HHs}$ & $\%$ 0-6 population & $\begin{array}{l}\% \text { Female popula- } \\
\text { tion }\end{array}$ & $\begin{array}{l}\% \text { of } \mathrm{HHs} \text { without } \\
\text { lands }\end{array}$ \\
\hline Island & 2.59 & 0.67 & 0.38 & 2.96 & 0.68 & 13.75 \\
\hline Coastal front & 2.64 & 1.23 & 1.48 & 10.95 & 0.85 & 10.58 \\
\hline Inland & 2.45 & 11.83 & 11.32 & 10.46 & 11.30 & 10.15 \\
\hline Riverine & 2.88 & 20.54 & 22.35 & 20.63 & 21.80 & 21.68 \\
\hline Overall & 2.64 & 35.34 & 35.53 & 43.04 & 34.61 & 42.42 \\
\hline $\begin{array}{l}\text { Geographical Loca- } \\
\text { tion }\end{array}$ & $\begin{array}{l}\text { Overall Backward- } \\
\text { ness }\end{array}$ & $\begin{array}{l}\% \text { of HHs without } \\
\text { safe drinking } \\
\text { water }\end{array}$ & $\begin{array}{l}\% \text { of HHs with- } \\
\text { out banking } \\
\text { facility }\end{array}$ & Literacygap & $\begin{array}{l}\% \text { of HHs income } \\
\text { less than } \\
\text { ₹ } 5000\end{array}$ & $\begin{array}{l}\% \text { of Aged popu- } \\
\text { lation } \\
(60+\text { Yrs. })\end{array}$ \\
\hline Island & 2.59 & 75.89 & 43.25 & 7.80 & 15.87 & 2.75 \\
\hline Coastal front & 2.64 & 82.29 & 31.44 & 8.98 & 8.55 & 1.40 \\
\hline Inland & 2.45 & 86.23 & 10.79 & 11.71 & 10.84 & 11.07 \\
\hline Riverine & 2.88 & 77.03 & 20.37 & 22.99 & 22.49 & 22.62 \\
\hline Overall & 2.64 & 88.81 & 32.60 & 13.59 & 34.88 & 35.09 \\
\hline
\end{tabular}

Table 9 Model fitting information

\begin{tabular}{|c|c|c|c|c|c|c|}
\hline \multirow[t]{2}{*}{ Model } & \multicolumn{3}{|c|}{ Model Fitting Criteria } & \multicolumn{3}{|c|}{ Likelihood Ratio Tests } \\
\hline & AIC & $\mathrm{BIC}$ & $\begin{array}{l}-2 \text { Log } \\
\text { Likelihood }\end{array}$ & Chi-Square & df & Sig. \\
\hline Intercept Only & 196.402 & 221.078 & 183.409 & & & \\
\hline Final & 251.872 & 394.945 & 87.917 & 94.438 & 12 & .002 \\
\hline
\end{tabular}


Table 10 Pseudo R-Square and Goodness-of-Fit

Table 11 Classification

Table 12 Likelihood Ratio Tests

Table 13 Parameter Estimates

\begin{tabular}{|c|c|c|c|c|c|c|}
\hline \multicolumn{2}{|c|}{ Pseudo R-Square } & \multicolumn{5}{|c|}{ Goodness-of-Fit } \\
\hline Cox and Snell & Nagelkerke & McFadden & Pearson & 167.720 & 202 & 0.432 \\
\hline 0.298 & 0.221 & 0.044 & Deviance & 78.035 & 202 & 0.031 \\
\hline
\end{tabular}

\begin{tabular}{lllll}
\hline Observed & \multicolumn{2}{l}{ Geographical locations } & \\
\cline { 2 - 5 } & $\begin{array}{l}\text { Island \& Coastal } \\
\text { front }\end{array}$ & Riverine/ estuarine & Inland & Per cent Correct \\
\hline Island \& Coastal front & 4 & 43 & 18 & 6.06 \\
Riverine/ estuarine & 43 & 2 & 20 & 66.16 \\
Inland & 18 & 22 & 26 & 27.69 \\
Overall Percentage & 49.39 & 8.78 & 41.83 & 50.87 \\
\hline
\end{tabular}

\begin{tabular}{|c|c|c|c|c|c|c|}
\hline \multirow[t]{2}{*}{ Backwardness } & \multicolumn{3}{|c|}{ Model Fitting Criteria } & \multicolumn{3}{|c|}{ Likelihood Ratio Tests } \\
\hline & $\begin{array}{l}\text { AIC of } \\
\text { Reduced Model }\end{array}$ & $\begin{array}{l}\text { BIC of } \\
\text { Reduced Model }\end{array}$ & $\begin{array}{l}-2 \text { Log Likelihood of } \\
\text { Reduced Model }\end{array}$ & $\begin{array}{l}\text { Chi- } \\
\text { Square }\end{array}$ & df & Sig. \\
\hline Intercept & 219.525 & 331.012 & 76.525 & .183 & 12 & .317 \\
\hline female & 238.767 & 369.074 & $102.647^{\mathrm{a}}$ & 17.629 & 12 & .001 \\
\hline child & 242.011 & 361.328 & $101.021^{\mathrm{a}}$ & 14.033 & 12 & .207 \\
\hline land & 221.762 & 335.870 & $78.542^{\mathrm{a}}$ & 13.589 & 12 & .002 \\
\hline water & 223.412 & 348.870 & $76.512^{\mathrm{a}}$ & 42.851 & 12 & .001 \\
\hline income & 247.267 & 371.882 & $104.467^{\mathrm{a}}$ & 14.889 & 12 & .001 \\
\hline bank & 238.318 & 365.471 & $92.329^{\mathrm{a}}$ & 7.481 & 12 & .067 \\
\hline
\end{tabular}

The chi-square statistic is the difference in $-2 \log$-likelihoods between the final model and a reduced model. The reduced model is formed by omitting an effect from the final model. The null hypothesis is that all parameters of that effect are 0 .

a. Unexpected singularities in the Hessian matrix are encountered. This indicates that either some predictor variables should be excluded or some categories should be merged.

\begin{tabular}{|c|c|c|c|c|c|c|c|c|c|}
\hline \multicolumn{2}{|c|}{ Backwardness } & \multirow[t]{2}{*}{ B } & \multirow[t]{2}{*}{$\begin{array}{l}\text { Std. } \\
\text { Error }\end{array}$} & \multirow[t]{2}{*}{ Wald } & \multirow[t]{2}{*}{ df } & \multirow[t]{2}{*}{ Sig. } & \multirow[t]{2}{*}{$\operatorname{Exp}(B)$} & \multicolumn{2}{|c|}{$\begin{array}{l}95 \% \text { Confidence } \\
\text { Interval for } \operatorname{Exp}(B)\end{array}$} \\
\hline & & & & & & & & $\begin{array}{l}\text { Lower } \\
\text { Bound }\end{array}$ & $\begin{array}{l}\text { Upper } \\
\text { Bound }\end{array}$ \\
\hline \multirow[t]{7}{*}{1.00} & Intercept & -14.410 & 3.946 & 13.336 & 1 & .000 & & & \\
\hline & female & 1.019 & .887 & 505.112 & 1 & .000 & 18.212 & .580 & .734 \\
\hline & child & -1.455 & 1.153 & 1.593 & 1 & .207 & 3.287 & .437 & 42.017 \\
\hline & land & 2.733 & 2.202 & 1.540 & 1 & .001 & .067 & .001 & 5.871 \\
\hline & water & 1.222 & 2.287 & .236 & 1 & .001 & 3.167 & .029 & 287.541 \\
\hline & income & 1.872 & 1.311 & 1.321 & 1 & .001 & .231 & .019 & 1.978 \\
\hline & bank & -1.983 & 2.703 & .538 & 1 & .067 & .134 & .002 & 26.541 \\
\hline \multirow[t]{7}{*}{2.00} & Intercept & -17.962 & 3.830 & 21.998 & 1 & .000 & & & \\
\hline & female & 2.179 & .000 & . & 1 & .207 & 5.567 & .567 & .667 \\
\hline & child & 1.639 & 1.160 & 1.995 & 1 & .158 & 5.148 & .530 & 50.004 \\
\hline & land & -1.775 & 1.956 & .824 & 1 & .364 & .170 & .004 & 7.832 \\
\hline & water & 1.846 & 2.309 & 639 & 1 & .424 & 6.334 & .069 & 585.180 \\
\hline & income & -.736 & 1.289 & .326 & 1 & .568 & .479 & .038 & 5.993 \\
\hline & bank & -3.137 & 2.715 & 1.335 & 1 & .248 & .043 & .000 & 8.887 \\
\hline
\end{tabular}

a. The reference category is: 1.00 
Plate 1 a Women have evacuated and sited at Cyclone -shelter in Kakdwip during cyclone BULBUL in November 2019, b Severe embankment breaching in Mousani at Namkhana during cyclone $Y A A S$ in May 2021, c Embankment breaching and saline water intrusion at Ghoramara Island in Sagar during cyclone $Y A A S$ in May 2021 and $\mathbf{d}$ Severe inundation in near G-Plot due to AMPHAN cyclone May 2020

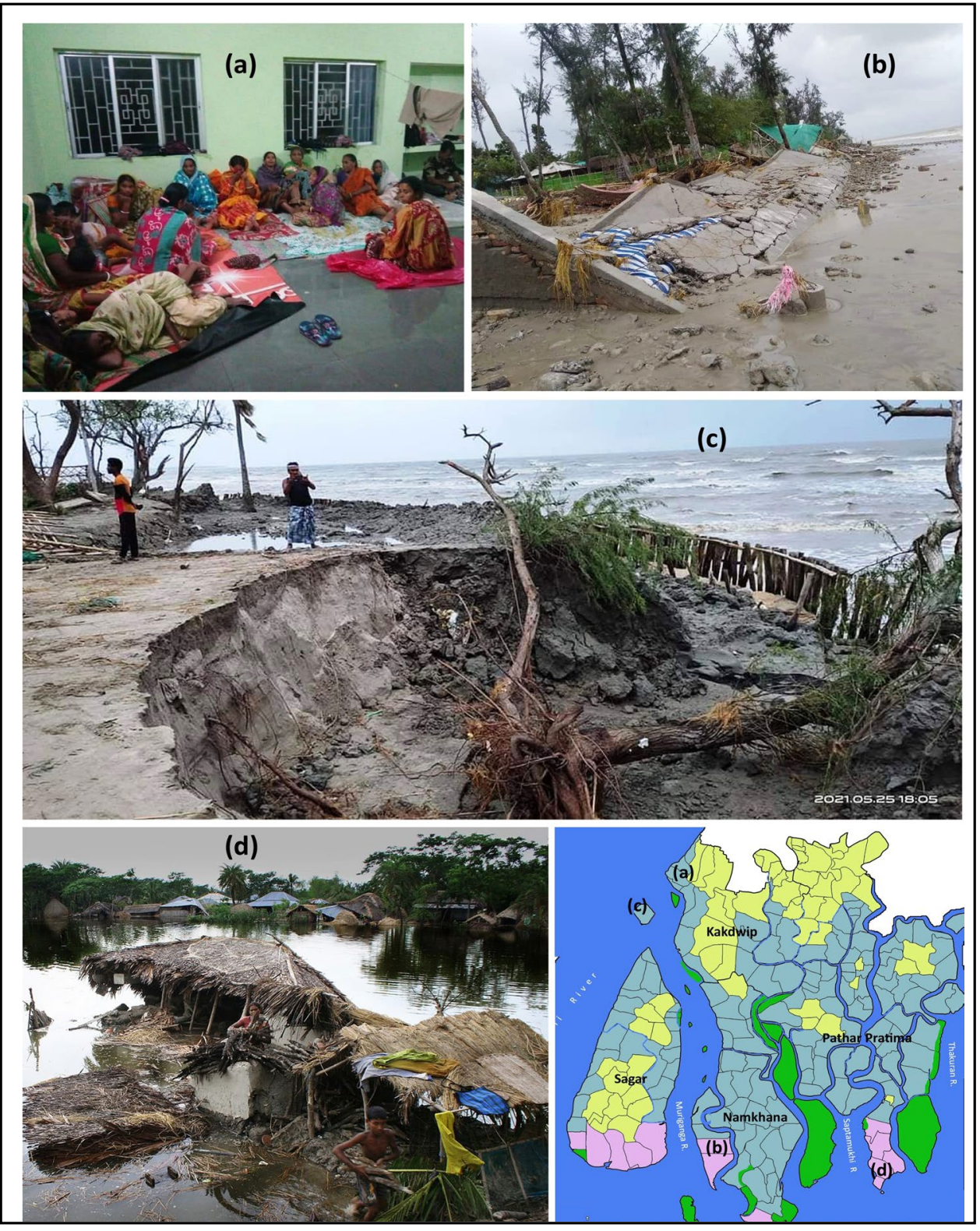

(Dintwa et al. 2019). Further, the study also tries to identify the contributing factors for the overall high to very high backward villages in different geographical locations (i.e. inland and riverine/ estuarine) for proper adaptation and methodology.

This research has been conducted by taking into account a group of indicators under five components that are related to various facets of quality of life and regional backwardness (Basu and Das 2020). Through the identification of high to very high backward villages, it has exposed some significant facts. Villages located within the buffer of $5 \mathrm{~km}$ from coastal front and riverine/ estuarine areas of Sagar, Pathar Pratima and Namkhana blocks have emerged as West Bengal delta's significant anxiety locations. Nearly $35 \%$ population with higher child and female population settled in this anxiety location have not facilitated to access the safe drinking water at a large (nearly $88 \%$ ). For better policy framing the sensitivity, adaptive capacity of this village need to be study in light of IPCC framework. Recent researches like INFORM analysis, READINESS index can also determine how the regional susceptibility can be mitigate with proper planning.

CRediT authorship contribution statement Manas Mondal: Conceptualization, Design of study, Formal analysis, Writing - original draft. Subrata Haldar: Funding acquisition. Anupam Biswas: Funding acquisition. Somnath Mandal: Funding acquisition. Subhasis Bhattacharya: Conceptualization, Design of study, Formal analysis, Writing - original draft, Writing- review \& editing. Suman Paul: Conceptualization, Design of study, Funding acquisition, Formal analysis, Writing - original draft, Writing - review \& editing. 
Data Availability Statement (DAS) appears in an article The data support the findings of the study is publicly available in websites of in Office of the Registrar General \& Census Commissioner, India (PCA, HLPCA) through https://census india.gov.in/2011 census/dchb/1917_ PART_B_DCHB_SOUTH\%20TWENTY\%20FOUR\%20PARGANAS. pdf, https://censusindia.gov.in/2011census/HLO/HL_PCA/Houselisting-housing-WB.html and Socio-economic caste census by the Ministry of Rural Development through https://secc.gov.in/homePageLgd. $\mathrm{htm}$. The authors also confirms about the dataset used for study is attached with Supplementary Sheet (in.xls format) with the manuscript.

Funding This article is one of the outputs of a research undertaking by the Dept. of Geography in collaboration with Dept. of Economics, Sidho-Kanho-Birsha University, Purulia, West Bengal, India, funded by the Dept. of Science \& Technology \& Biotechnology (WB-DSTBT) -- (DSTBT Grant Number: ST/P/ S\&T/5G-12/2018 dated 25.02.2019) and Ph.D. research by Mr. Manas Mondal.

\section{Declarations}

Conflict of Interest The authors declare that they have no known competing financial interests or personal relationships that could have appeared to influence the work reported in this paper.

\section{References}

Abdi H, Williams LJ (2010) Principal component analysis. Wiley Interdisciplinary Reviews: Computational Statistics 2(4):433-459

Abid M, Scheffran J, Schneider UA, Ashfaq M (2015) Farmers' perceptions of and adaptation strategies to climate change and their determinants: the case of Punjab province, Pakistan. Earth Syst Dynam 6:225-243. https://doi.org/10.5194/esd-6-225-2015

Aksha SK, Juran L, Resler LM, Zhang Y (2018) An Analysis of Social Vulnerability to Natural Hazards in Nepal Using a Modified Social Vulnerability Index. Int J Disaster Risk Sci. 10:103-116. https:// doi.org/10.1007/s13753-018-0192-7

Alam GMM (2017) Livelihood Cycle and Vulnerability of Rural Households to Climate Change and Hazards in Bangladesh. Environmental Management 59:777-791. https://doi.org/10.1007/ s00267-017-0826-3

Alam GMM, Alam K, Shahbaz M, Clarke ML (2017) Drivers of vulnerability to climatic change in riparian char and river-bank households in Bangladesh: implications for policy, livelihoods and social development. Ecol Indic. 72:23-32

Angadi DP (2012) Regional Disparities in Agricultural DevelopmentA Case Study of Belgium District of Karnataka State, India. Regional Symbiosis 20:68-86

Bakshi S, Chawla A, Shah M (2015) Regional disparities in India A moving frontier. Econ Polit Wkly. 50(1):44-52

Basu T, Das A (2020) Identification of backward district in India by applying the principal component analysis and fuzzy approach: A census based study. Socio-Economic Planning Sciences. https:// doi.org/10.1016/j.seps.2020.100915

Banerjee K, Senthilkumar B, Purvaja R, Ramesh R (2012) Sedimentation and trace metal distribution in selected locations of Sundarbans mangroves and Hooghly estuary, northeast coast of India. Environmental Geochemistry and Health 34(1):27-42

Bergstrand K, Mayer B, Brumback B (2015) Assessing the Relationship between Social Vulnerability and Community Resilience to Hazards. Soc. Indic. Res. 122:391-409. https://doi.org/10.1007/ s11205-014-0698-3
Bjarnadottir S, Li Y, Stewart MG (2011) Social vulnerability index for coastal communities at risk to hurricane hazard and a changing climate. Natural Hazards 59:1055-1075. https://doi.org/10.1007/ s11069-011-9817-5

Boruff BJ, Cutter SL (2007) The environmental vulnerability of Caribbean Island nations. Geographical Review 97(1):24-45

Chang SE, Yip JZK, van-Zijll-de J (2015) Using vulnerability indicators to develop resilience networks: a similarity approach. Natural Hazards 78:1827-1841. https://doi.org/10.1007/ s11069-015-1803-x

Chen W, Cutter SL, Emrich CT, Shi P (2013) Measuring social vulnerability to natural hazards in the Yangtze River Delta Region, China. International Journal of Disaster Risk Sc. 4(4):169-181. https://doi.org/10.1007/s13753-013-0018-6

Choudhury AM, Neelormi S, Quadir DA, Mallick S, Ahmed AU (2005) Socio-economic and physical perspectives of water related vulnerability to climate change: Results of field study in Bangladesh. Sci Cult. 71(7-8):225-238

Cutter SL, Boruff BJ, Shirley WL (2003) Social vulnerability to environmental hazards. Social Science Quarterly 84(2):242-261. https://doi.org/10.1111/1540-6237.8402002

Cutter SL, Morath DP (2014) The evolution of the social vulnerability index (SoVI). In: Birkmann J (ed) Measuring vulnerability to natural hazards: Towards disaster resilient societies, 2nd edn. United Nations University Press, New York, pp 304-321

Das B, Mistri A (2013) Household quality of living in Indian states: analysis of 2011 census. Environ and Urbanization Asia 4(1):151171. https://doi.org/10.1177/0975425313477759

Das S, Amit G, Sugata H, Ghosh T, Ricardo SC, Samanta S (2020) Linking IPCC AR4 \& AR5 frameworks for assessing vulnerability and risk to climate change in the Indian Bengal Delta. Progress in Disaster Science 7:100110. https://doi.org/10.1016/j.pdisas. 2020.100110

Desai IP (1984) Should 'Caste' Be the Basis for Recognising Backwardness? Economic and Political Weekly 19(28):1106-1116

Dholakia RH (2003) Regional disparity in economic and human development in India. Econ Polit Wkly. 38(39):4166-4172

Dintwa KF, Letamo G, Navaneetham K (2019) Measuring social vulnerability to natural hazards at the district level in Botswana. Jàmbá Journal of Disaster Risk Studies 11(1). https://doi.org/10. 4102/jamba.v11i1.447

Dube OP, Sekhwela MBM (2008) Indigenous knowledge, institutions and practices for coping with variable climate in the Limpopo Basin in Botswana'. In: Leary $\mathrm{N}$ et al (eds) Climate and adaptation 71-89. Earthscan, London

Dubey S, Biswas P, Ghosh R, Chatterjee S, Dubey MJ, Chatterjee S, Lahiri D, Lavie CJ (2020) Psychosocial impact of COVID-19. Diabetes \& Metabolic Syndrome: Clinical Research \& Reviews. https://doi.org/10.1016/j.dsx.2020.05.035

Dwarakish GS, Vinay SA, Natesan U, Asano T, Kakinuma T, Venkataraman K, Pai J, Babita MK (2009) Coastal vulnerability assessment of the future sea level rise in Udupi Coastal Zone of Karnataka State, west coast of India. Ocean and Coastal Management 52:467-478

Emmanuel M, Manyenab B, Collin AE (2017) An approach for measuring social vulnerability in context: The case of flood hazards in Muzarabani district, Zimbabwe. Geoforum 86:103-117. https:// doi.org/10.1016/j.geoforum.2017.09.008

Eriksen S, Kelly P (2007) Developing credible vulnerability indicators for climate adaptation policy assessment. Mitig Ada Glob Change 12(4):495-524

Fahrmeir L, Lang S (2001) Bayesian inference for generalized additive mixed models based on markov random field priors. J. R. Stat. Soc. Ser. C (Appl. Stat.) 50:201-220 
Fuchs S, Birkmann J, Glade T (2012) Vulnerability assessment in natural hazard and risk analysis: Current approaches and future challenges. Natural Hazards 64(3):1969-1975

Füssel HM (2010) How inequitable is the global distribution of responsibility, capability, and vulnerability to climate change: a comprehensive indicator-based assessment. Glob. Environ. Change 20:597-611

Ghosh N, Kar S, Sharma S (2007) Inequalities of Income Opportunities in a Hilly State: A Study of Uttarakhand. Institute of Economic Growth, Working Paper S. No. E/287/2007 Global Media Report (2015) Accessed through https://www.mckinsey. com/industries/technology-media-and-telecommunications/ourinsights/global-media-report-2015

Gopal B, Chauhan M (2006) Biodiversity and its conservation in the Sundarban mangrove ecosystem. Aquatic Sciences 68(3):338-354

Government of India (2013) Report of the committee for evolving a composite development index of states. Ministry of Finance, Government of India 2013. http://www.iIndiaenvironmentportal.org. in/content/381622/report-of-the-committee-for-evolving-a-compo site-developm ent-index-of-states-raghuram-rajan-panel-report/

Ghosh U, Bose S, Bramhachari R (2018) Living on the edge: climate change and uncertainty in the Indian Sundarbans. Accessed through https://opendocs.ids.ac.uk/opendocs/bitstream/handle/ $20.500 .12413 / 13597$

Govinda R, Varghese NV (1993) Quality of primary school in India: a case study of Madhya Pradesh. India Higher Education Report. UNESCO-IIEP, UNDP

Hahn MB, Riederer AM, Foster SO (2009) The livelihood vulnerability index: A pragmatic approach to assessing risks from climate variability and change. A case study in Mozambique. Global Environmental Change 19(1):74-88. https://doi.org/10.1016/j.gloen vcha.2008.11.002

Hegde AV, Reju VR (2007) Development of coastal vulnerability index for Mangalore Coast, India. Journal of Coastal Research 23:1106-1111

Helms JE, Kevin TH, Terry L, Venus S, Mifsud A (2006) Treating Cronbach's Alpha Reliability Coefficients as Data in Counseling Research. The Counseling Psychologist 34(5):630-660. https:// doi.org/10.1177/0011000006288308

Hossain M (1993) Economic effects of riverbank erosion: some evidence from Bangladesh. Disaster 17(1):25-32

Hotelling H (1933) Analysis of a Complex of Statistical Variables into Principal Components. Journal of Educational Psychology 24:417-441

Holand IS, Lujala P (2013) Replicating and adapting an index of social vulnerability to a new context: A comparison study for Norway. Professional Geographer 65(2):312-328

House listing and Housing Census Data (HLPCA) (2011) Accessed through https://censusindia.gov.in/2011census/hlo/hlo_table/hlo_ table_West_Bengal.html

Hummell BMD, Cutter SL, Emrich CT (2016) Social vulnerability to natural hazards in Brazil. International Journal of Disaster Risk Science 7(2):111-122

Islam MR, Hasan M (2015) Climate-induced human displacement: A case study of Cyclone Aila in the south-west coastal region of Bangladesh. Natural Hazards 81(2):1051-1071

IPCC (2014) Climate change 2014: Impacts, adaptation and vulnerability, Fifth assessment report. Intergovernmental Panel on Climate Change. Cambridge University Press, Cambridge, UK

John BP (1999) Growth-pole Strategies in Regional Economic Planning: A Retrospective View: Part 2. Implementation and Outcome 10(1080/004209899):2971

Juran L, Trivedi J (2015) Women, gender norms, and natural disasters in Bangladesh. Geographical Review 105(4):601-611
Kenova V, Jonasson P (2006) Quality Online Banking Services. Technical Report, Jonkoping International Business School

Krishna G (1989) Trends in Regional Disparities in India. Asian Profile 17(3):243-261

Krishnan P, Ananthan PS, Purvaja R (2018) Framework for mapping the drivers of coastal vulnerability and spatial decision making for climate-change adaptation: A case study from Maharashtra, India. Ambio 48:192-212. https://doi.org/10.1007/s13280-018-1061-8

Letsie MM, Grab SW (2015) Assessment of social vulnerability to natural hazards in the Mountain Kingdom of Lesotho. Mountain Research and Development 35(2):115-125

Liu B, Li Y (2016) Social vulnerability of rural households to flood hazards in western mountainous regions of Henan province, China. Natural Hazards and Earth System Sciences 16:11231134. https://doi.org/10.5194/nhess-16-1123-2016

Manthalu G, Nkhoma N, Kuyeli S (2010) Simple Versus composite indicators of socioeconomic status in resource allocation formuiae: the case of the district resource allocation formula in 20 Malawi. BMC Health Services Research 10(6):1-8 http://www. biomedcentral.com/1472-6963/10/6n

Mahendra RS, Mohanty PC, Kumar ST, Shenoi SSC, Nayak S (2010) Coastal multi-hazard vulnerability mapping: A case study along the Coast of the Nellore District, Andhra Pradesh, East Coast of India. Italian Journal of Remote Sensing 42:67-76

Majumder R (2005) Infrastructure and Regional Development: Interlinkages in India. Indian Economic Review 40(2):167-184 https:// www.jstor.org/stable/29793842

Mondal M, Paul S, Bhattacharya S, Biswas A (2020) Micro-level Assessment of Rural Societal Vulnerability of Coastal Regions: An Insight into Sagar Island, West Bengal. India. Asia-Pacific Journal of Rural Development 30(1-2):55-88. https://doi.org/10. $1177 / 1018529120946230$

Mondal M, Haldar S, Biswas A, Mandal S, Bhattacharya S, Paul S (2021) Modeling cyclone-induced multi-hazard risk assessment using analytical hierarchical processing and GIS for coastal West Bengal. India. Regional Studies in Marine Science 44:101779. https://doi.org/10.1016/j.rsma.2021.101779

Motsholapheko MR, Vanderpost C, Kgathi DL (2011) Rural livelihoods and household adaptation to desiccation in the Okavango Delta, Botswana. Journal of Water and Climate Change 3(4):300 316. https://doi.org/10.1016/j.pce.2011.08.004

Nayak LT, Narayankar DS (2009) Identification of Regional Disparities in levels of development in Bellary District-Karnataka. Indian Journal of Regional Science 41(1):37-47

Nunnally JC (1978) Psychometric theory. 2nd Edition, McGraw-Hill, New York

Panthil J, Aryal S, Dahal P, Bhandari P, Krakauer NY, Pandey VP (2015) Livelihood vulnerability approach to assessing climate change impacts on mixed agro-livestock smallholders around the Gandaki River Basin in Nepal. Reg Environ Change. https://doi. org/10.1007/s10113-015-0833-y

Papathoma-Kohle M, Kappes M, Keiler M, Glade T (2011) Physical vulnerability assessment for alpine hazards: State of the art and future needs. Natural Hazards 58(2):645-680

Paul AK, Alam MM, Haque MA, Hussain MA, Islam MS, Mahfuj MS, Das SK (2021) Gender-specific morphological growth patterns of the Estuarine Mud Crab Scylla olivacea in North-eastern Sundarbans, Bangladesh. Thalassas 37:521-529. https://doi.org/ 10.1007/s41208-021-00307-2

Paul S, Karan S, Bhattacharya BD (2020) Daily variability of copepods after successive tropical cyclones in the Ganges River estuary of India. Estuarine, Coastal and Shelf Science 246:107048.https:// doi.org/10.1016/j.ecss.2020.107048

Pituch KA, Stevens PJ (2015) Applied Multivariate Statistics for the Social Sciences Analyses with SAS and IBM's SPSS. Routledge Publication. 10(4324/978):1315814919 
Primary Census Abstract (2011) District South 24 Parganas. (Part A). accessed through https://censusindia.gov.in/pca/default.aspx

Rasheed AA, Zewotir T, Ramroop S (2016) Semi-parametric Multinomial Ordinal Model to Analyze Spatial Patterns of Child Birth Weight in Nigeria. Int. J. Environ. Res. Public Health 13:1145. https://doi.org/10.3390/ijerph13111145

Rufat S, Tate E, Burton CG, Maroof SA (2015) Social vulnerability to floods: Review of case studies and implications for measurement. International Journal of Disaster Risk Reduction 14:470-486. https://doi.org/10.1016/j.ijdrr.2015.09.013

Rutstein SO (2000) Factors associated with trends in infant and child mortality in developing countries during the 1990s. Bull. World Health Organisation 78:1256-1270

Saboor A, Khal A, Hussain A, Ali I, Mahmood K (2015) Multidimensional deprivations in Pakistan: regional variations and temporal shifts. Q Rev Econ Finance 56:57-67. https://doi.org/10.1016/j. qref.2015.02.007

Sahana M, Rehman S, Paul AK, Sajjad H (2019) Assessing socio-economic vulnerability to climate change-induced disasters: evidence from Sundarban Biosphere Reserve. Geology, Ecology, and Landscapes, India. https://doi.org/10.1080/24749508.2019.1700670

Sahana M, Rehman S, Ahmed R, Sajjad H (2020) Analyzing climate variability and its effects in sundarban biosphere reserve, India: reaffirmation from local communities. Environ. Dev. Sustainability. https://doi.org/10.1007/s10668-020-00682-5

Sarker MH, Haque I, Alam M, Koudstal R (2003) Rivers chars and char dwellers of Bangladesh. Interna J River Basin Manag. 1(1):61-80

Satapathy S, Porsche I, Rolker D, Bhattacharya S, Tomar S, Nair S (2014) A framework for climate change vulnerability assessments. Project on Climate Change Adaptation in Rural Areas of India (CCA RAI), New Delhi, India
Sekhar CC, Indrayan A, Gupta SM (1991) Development of an index of need for health resources for Indian. Int J Epidemiol. 20(1):246-250

Sen AA (1999) Plan for Asia's Growth. Asia Week. http://www. asiaweek.com/magazine/99/1008/viewpoint.html

Sen A (1993) Capability and well-being. In: Nussbaum M, Sen A (eds) The quality of life. Clarendon Press, Oxford

Singh R (2006) Regional Disparities in Levels of Socio-economic Development in Post Reform Period: A District Level Analysis. Annals of NAGI 26(2):87-94

Socio-Economic Caste Census, India (2011) Accessed through https:// secc.gov.in/welcome

Szabo S, Brondizio E, Renaud FG, Hetrick S, Nicholls RJ, Matthews Z (2016) Population dynamics, delta vulnerability and environmental change: comparison of the Mekong, Ganges-Brahmaputra and Amazon delta regions. Sustainability Science 11(4):539-554

TERI (2014) Assessing Climate Change vulnerability and adaptation strategies for Maharashtra: Maharashtra State Adaptation Action Plan on Climate Change (MSAAPC). Report 2010GW01. The Energy and Resources Institute Project, New Delhi

Vincent K, Cull T (2010) A household Social Vulnerability Index (HSVI) for evaluating adaptation projects in developing countries. In Proceedings of PEGNet conference 2010: Policies to foster and sustain equitable development in times of crises, Midrand

Vvas S, Kumaranayake L (2010) Constructing an area-based socioeconomic index: a principal components analysis approach. Health Policy and Planning 21(6):459-468. https://doi.org/10.1093/ heapol/czl029

Zhou Y, Li N, Wu WX, Wu JD, Shi PJ (2014) Local spatial and temporal factors influencing population and societal vulnerability to natural disasters. Risk Analysis 34(4):614-639 